This item was submitted to Loughborough's Research Repository by the author.

Items in Figshare are protected by copyright, with all rights reserved, unless otherwise indicated.

\title{
Aquatic insect bioconstructions modify fine-sediment entrainment and mobility
}

PLEASE CITE THE PUBLISHED VERSION

https://doi.org/10.1029/2021jf006399

\section{PUBLISHER}

American Geophysical Union (AGU)

VERSION

VoR (Version of Record)

\section{PUBLISHER STATEMENT}

This is an Open Access Article. It is published by American Geophysical Union (AGU) under the Creative Commons Attribution 4.0 International Licence (CC BY 4.0). Full details of this licence are available at: https://creativecommons.org/licenses/by/4.0/

\section{LICENCE}

CC BY 4.0

\section{REPOSITORY RECORD}

Mason, RJ, Stephen Rice, MF Johnson, Paul Wood, and D Vettori. 2022. "Aquatic Insect Bioconstructions Modify Fine-sediment Entrainment and Mobility”. Loughborough University. https://hdl.handle.net/2134/19292369.v1. 


\section{JGR Earth Surface}

\author{
RESEARCH ARTICLE \\ 10.1029/2021JF006399 \\ Key Points: \\ - Caddisfly (Trichoptera) larvae are \\ aquatic insects that build cases from \\ fine sediment, which may modify \\ sediment transport \\ - Dome shaped cases (family \\ Glossosomatidae) do not differ in \\ mobility from the sand particles they \\ are constructed from \\ - Tubular shaped cases (Limnephilidae \\ and Sericostomatidae) are more \\ mobile than sand grains and may \\ increase sand transport in rivers
}

\section{Supporting Information:}

Supporting Information may be found in the online version of this article.

Correspondence to:

R. J. Mason,

richard.mason@umu.se

\section{Citation:}

Mason, R. J., Rice, S. P., Johnson, M F., Wood, P. J., \& Vettori, D. (2022). Aquatic insect bioconstructions modify fine-sediment entrainment and mobility. Journal of Geophysical Research: Earth Surface, 127, e2021JF006399. https://doi. org/10.1029/2021JF006399

Received 17 AUG 2021

Accepted 20 DEC 2021

Author Contributions:

Conceptualization: R. J. Mason, S. P.

Rice, M. F. Johnson, P. J. Wood

Formal analysis: R. J. Mason

Methodology: R. J. Mason, S. P. Rice, M.

F. Johnson, P. J. Wood, D. Vettori

Supervision: S. P. Rice, M. F. Johnson,

P. J. Wood

Writing - original draft: R. J. Mason

Writing - review \& editing: R. J.

Mason, S. P. Rice, M. F. Johnson, P. J.

Wood, D. Vettori

\section{Aquatic Insect Bioconstructions Modify Fine-Sediment Entrainment and Mobility}

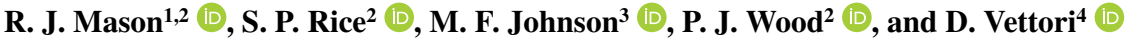 \\ ${ }^{1}$ Umeå University, Umeå, Sweden, ${ }^{2}$ Loughborough University, Loughborough, UK, ${ }^{3}$ University of Nottingham, Nottingham, \\ UK, ${ }^{4}$ Politecnico di Torino, Torino, Italy
}

\begin{abstract}
The importance of two-way interactions between animals and the physical hydraulic and sedimentological environment are increasingly recognized (e.g., zoogeomorphology). Caddisflies (Trichoptera) are a group of aquatic insects known for their bioconstructions, particularly cases built from fine sediment and silk. Caddisfly cases differ in size, shape and density from the incorporated sediment, and case construction may therefore affect the mobility of these sediments in rivers. However, although communities of caddisfly often use substantial quantities of sediment in case construction, the effect of these bioconstructions on sediment transport in rivers is unknown. We use a flume experiment to compare the bed shear stress required to transport (a) empty caddisfly cases and (b) individual sediment particles, following disaggregation from the case. The cases of three species were considered; two that construct different styles of tubular case (Potamophlax latipennis and Sericostoma personatum) and one that builds a domed case (Agapetus fuscipes). $P$. latipennis and $S$. personatum cases were easier to entrain than the sediment grains incorporated into them, whilst $A$. fuscipes cases were not. Despite their low mass, A. fuscipes cases required the most shear stress to transport them because their domed shape impeded rolling. These findings are important to understand how differences in case design between species, reflect different adaptation strategies to the turbulent hydraulic river habitat. Furthermore, the results suggest that un-attached tubular caddisfly cases may be preferentially transported over other particles on the river bed and thus, where caddisfly occur in high abundance, they may increase fluvial entrainment of sand.
\end{abstract}

Plain Language Summary The power of water allows rivers to shape the landscape, transporting sediment downstream, creating landforms and habitat. Rivers are teeming with life, which can also affect sediment transport. Caddisfly larvae are aquatic insects, many of which have adapted to underwater life by building structures (e.g., cases) from sediment and silk. By combining many sand particles into single cases, caddisfly may affect the river energy required to move this sand. We compared the hydraulic force required to move caddisfly cases versus the loose sand grains they were built from. Most caddisfly cases are tube shaped and construction of these cases made the incorporated sand easier to transport. As a result, case construction by most caddisfly species is expected to increase the downstream transport of sand in rivers. In contrast, dome shaped caddisfly cases were better able to resist downstream transport, thus subtle differences in case design between species can affect the sediment incorporated into them. Caddisflies are small (typically less than $3 \mathrm{~cm}$ length), but are extremely common in rivers (often over 1,000 individuals per $\mathrm{m}^{2}$ of riverbed) and therefore can potentially have important effects for sediment transport. We conclude that, whilst river sediment research has focused on hydraulic forces, small animals can have big impacts.

\section{Introduction}

The transport of sediment in rivers is a primary control on river morphology, habitat distribution and the ecosystem services that rivers provide. Consequently, considerable research has sought to understand fluvial sediment transport, from the scale of individual particles (e.g., Gomez \& Church, 1989; Wilcock et al., 2009) to catchment and global sediment fluxes (Hoffmann et al., 2010; Walling, 2009). At the grain scale, particle size and shape are fundamental controls on sediment mobility (Carling et al., 1992; Oakey et al., 2005; Shields, 1936). Furthermore, in river-beds, particles do not exist in isolation and grain interactions driven by differences in size and shape, including imbrication, packing, sorting, winnowing, hiding and armoring, affect particle entrainment, displacement and deposition (Dietrich et al., 1989; Parker \& Sutherland, 1990). However, until relatively recently, little consideration was given to the effects of biological activities on sediment transport (Corenblit et al., 2011; Naylor et al., 2002; Viles, 2019). Increasingly, research bridging fluvial geomorphology and ecology 
is providing a more holistic understanding, necessary for the sustainable management of rivers (Harvey \& Bertoldi, 2015; Johnson et al., 2019; Polvi \& Wohl, 2013).

Animals can alter both the effective size and shape of sediment particles as well as modifying grain interactions (Zoogeomorphology, Butler, 1995. For rivers see reviews e.g: Polvi \& Sarneel, 2018; Rice et al., 2012; Statzner, 2012). Spawning Salmonid fish (Gottesfeld et al., 2004), foraging benthivorous fish (Pledger et al., 2017; Rice et al., 2019) and crayfish (Johnson et al., 2010) can directly affect sediment transport by displacing sediment particles and may also destabilize water-worked grain structures, so that particles are both more exposed to hydraulic forces and require lower stresses to entrain. For example, spawning salmon are estimated to contribute almost half of bedload transport in four British Columbia stream (Hassan et al., 2008) and may influence river evolution at the landscape scale (Fremier et al., 2018). Whilst fluvial zoogeomorphic research has focused on larger taxa, small animals may have equally significant zoogeomorphic effects (Mason \& Sanders, 2021).

Aquatic insects are ubiquitous to rivers and often occur at high population densities (e.g., $10^{3}-10^{4}$ per $\mathrm{m}^{-2}$; Cardinale et al., 2004; Hershey \& Lamberti, 2001; Palmer, 1990). Aquatic insects are typically small ( $<25 \mathrm{~mm}$ length) and are extremely diverse in behavior and morphology. The zoogeomorphic importance of insects is well recognised in marine and terrestrial environments (Bétard, 2021; Groom, 2022), but less is known about how they affect sediment processes in rivers. Nevertheless, aquatic insects can have substantial effects on the entrainment and mobility of sediment (see review: Mason \& Sanders, 2021). Similar to fish and crayfish, insects may bioturbate sediment via locomotion and foraging activities. The stonefly Dinocras cephalotes, for example, erodes 200-400 $\mathrm{kg} \mathrm{m}^{-2} \mathrm{a}^{-1}$ of sand whilst foraging in gravel-beds (Statzner et al., 1996; Zanetell \& Peckarsky, 1996), whilst the mayfly Pseudiron centralis actively positions its body to create hydraulic structures which erode sand (Soluk \& Craig, 1990).

Aquatic insects can also alter the effective size and shape of sediment particles when they build structures (Bioconstruction; Viles, 2019). Caddisfly (Trichoptera) are dubbed "underwater architects" due to their bioconstructions (Wiggins, 2004). The diverse range of structures built by caddisfly larvae allow them to have zoogeomorphic effects far greater than expected from their small body size (Albertson \& Allen, 2015). Some caddisfly larvae, such as those of the family Hydropsychidae, construct silk nets secured between gravel particles on the river bed. Caddisfly nets may act to stabilize gravel beds, increasing the hydraulic shear stress required to mobilize gravel particles (Albertson et al., 2014; Johnson et al., 2009; Statzner et al., 1996), reducing the recurrence intervals of bed scouring floods (Cardinale et al., 2004).

Many caddisfly larvae also build cases from sand and organic material cemented together with silk (Figure 1). Cases built by caddisfly often occur at densities of several thousand per $\mathrm{m}^{2}$ (de Moor \& Ivanov, 2008; Mcneely \& Power, 2007; Wiggins, 2004). In a typical UK lowland stream in spring, Mason et al. (2019) found a mean abundance of 2,250 case-building caddisfly larvae per $\mathrm{m}^{2}$ using on average $37.57 \mathrm{~g} \mathrm{~m}^{-2}$ (and up to $138.83 \mathrm{~g} \mathrm{~m}^{-2}$ ) of mineral sediment. Consequently, whilst it is known that caddisflies bind a considerable amount of sand and fine gravel into cases on river bed surfaces (Mason et al., 2019), the effect of these bioconstructions on the mobility of incorporated sediment is unknown.

Cases construction is completed by most species of caddisfly (including net building taxa such as those considered by Albertson et al., 2014; Cardinale et al., 2004; Johnson et al., 2009, which build cases for pupation). However, case design and the timings of case construction and abandonment vary between species. Most caddisfly construct hollow tube-shaped cases early in their larval stage and enlarge them as they grow (e.g., families Limnephilidae and Sericostomatidae; Figures 1a and 1b). In contrast, Glossosomatidae species build a dome shaped case (Figure 1c) which is usually abandoned and built afresh each instar (growth stage; Becker, 2005; Houghton \& Stewart, 1998). Consequently, empty caddisfly cases are commonly found in rivers because they are discarded following pupation and sometimes between instars (Wiggins, 2004). Case design may play an important role in the transport of caddisfly cases; rods and spherical sediment grains are more readily transported than dome shapes because they are able to roll, reducing friction with the river bed (Carling et al., 1992; Oakey et al., 2005) and the same may be true for cases. Caddisfly larvae may fix their cases to the river bed during pupation which is expected to have a stabilizing effect on incorporated sediment until the attachments degrade. However, for the majority of their lifecycle, most caddisfly cases are un-attached and their zoogeomorphic affects unknown. 

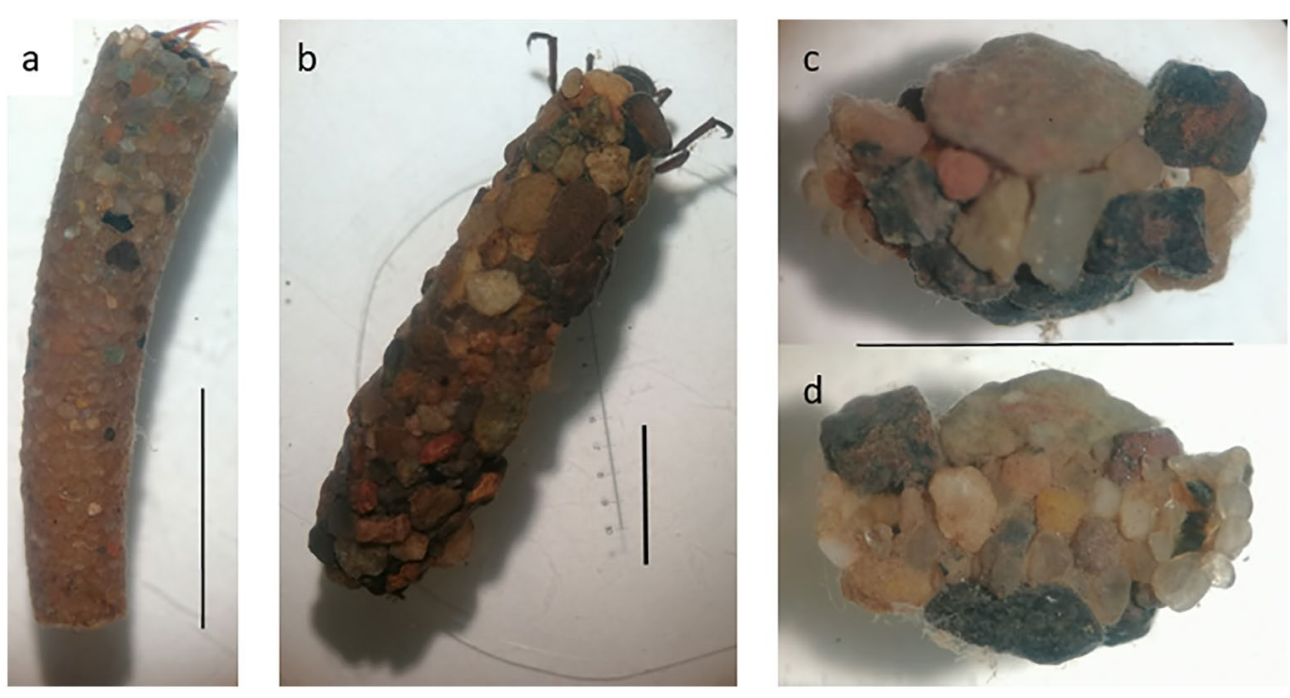

Figure 1. The design of caddisfly cases. (a) Sericostomatidae-Sericostoma personatum constructs a tubular, curved case, from fine sand. (b) Limnephilidae-Potamophylax latipennis uses coarser sand and fine gravel to build tubular cases. Cases of both these species are lined internally with silk. (c) Glossosomatidae-Agapetus fuscipes dorsal view and (d) ventral view. A. fuscipes builds a domed shaped case of coarse sand and gravel. Scale bar indicates $5 \mathrm{~mm}$.

The hydraulic transport of caddisfly cases has been studied from an ecological perspective to understand how case architecture affects entrainment during involuntary drift, which is a risk for the survival of larvae (Dodds \& Hisaw, 1925; Limm \& Power, 2011; Otto \& Johansson, 1995). Resistance to entrainment is divided into passive resistence (dependent on the mass and shape of the case and larvae) and active resistence (dependent on the behavior of the larvae). Caddisfly cases constructed from mineral sediment presumably provide resistance to drift due to their mass (Dodds \& Hisaw, 1925; Webster \& Webster, 1943) allowing larvae to expend less energy actively resisting drift (Waringer, 1989) and reducing drift distance if larvae are entrained. For example, Potamophylax latipennis (Limnephilidae) larvae build large mineral cases (Figure 1b) and are usually only entrained for short periods, saltating over the river bed (Lancaster et al., 2006).

Caddisfly larvae combine grains of sand and fine gravel into a single aggregate case, creating particles of a shape and density otherwise not found in rivers. Case construction increases the effective size of sediment particles, which typically would be expected to reduce mobility (Shields, 1936). However, cases are also hollow, so have a low density relative to similar sized mineral particles and protrude further into the flow than individual grains, both of which may increase their mobility. Furthermore, case design may play an important role in their mobility particularly when comparing cases of different shapes (e.g., tubes and domes). We investigated the effects of caddisfly case construction on the bed shear stress required to entrain the fine sediment directly incorporated within them. We did this for three species that differ in case design (Figure 1), comprising two tubular case building taxa (P. Latipennis and Sericostoma personatum) and one dome-building species (Agapetus fuscipes). Together these caddisfly families account for nearly $80 \%$ of the sediment used by case-building caddisfly in Mason et al.'s (2019) study of a small lowland UK stream. In this study, the bed shear stress required to entrain empty cases was assessed in a hydraulic flume. We considered empty cases in order to understand the zoogeomorphic effect of the bioconstruction itself, rather than the behavior of the larvae (e.g., Otto, 1976). Following this, the cases were disaggregated into their constituent sediment grains and the entrainment measurements were repeated to provide a direct comparison between case bioconstruction and incorporated sediment. The following research questions were investigated:

1. Does the construction of caddisfly cases alter the bed shear stress required to mobilize the sediment incorporated within them?

2. Does the bed shear stress required to mobilize caddisfly cases vary between species with differing case designs? 


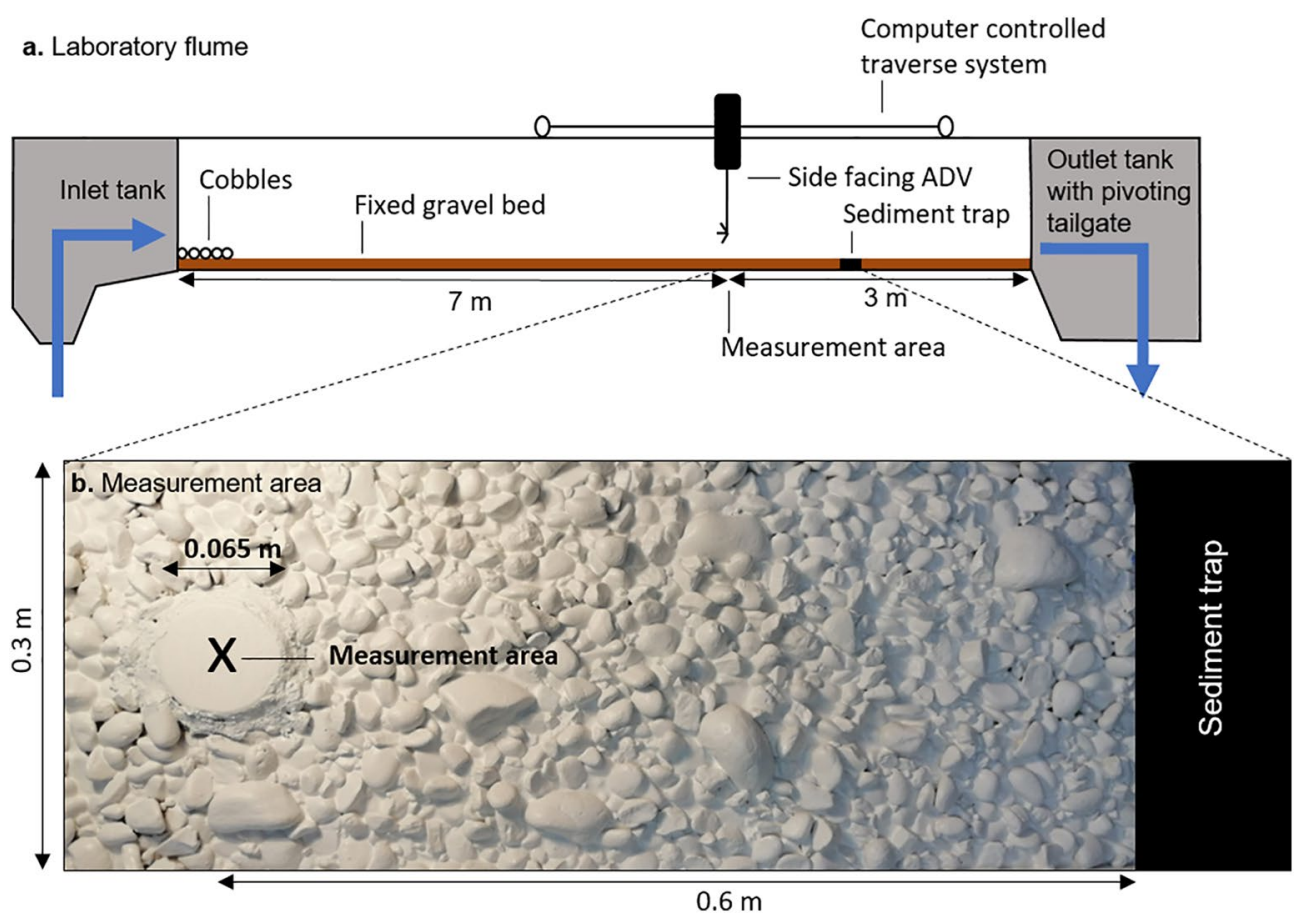

Figure 2. The laboratory flume setup. (a) Schematic of laboratory flume: water recirculates over a raised, fixed, gravel-bed $\left(D_{50}=15 \mathrm{~mm}\right)$. Large cobbles were positioned next to the flume inlet to ensure the development of fully turbulent flow conditions. Entrainment was measured from a flat platform located $7 \mathrm{~m}$ downstream from flume inlet. (b) Plan view of the flat platform from which entrainment was measured and the sediment trap.

\section{Materials and Methods}

\subsection{Caddisfly Case Collection}

Three species of caddisfly with different case designs were studied. Sericostomatidae, S. personatum cases are tubular in shape, slightly curved and narrowing toward the posterior (length $=\sim 15 \mathrm{~mm}$; Figure 1a) and constructed from fine sand (median particle size, $\mathrm{D}_{50}=0.27 \mathrm{~mm}$, Mason et al., 2019). The Limnephilidae, P. latipennis (Figure 1b) builds large cases ( $22 \mathrm{~mm}$ long) from coarse sand $\left(\mathrm{D}_{50}=1.31 \mathrm{~mm}\right.$; Mason et al., 2019) and although they sometimes incorporate organic sediment, in this experiment their cases were exclusively mineral. Glossosomatidae, A. fuscipes also primarily use coarse sand $\left(\mathrm{D}_{50}=0.94 \mathrm{~mm}\right.$; Mason et al., 2019) to build domeshaped cases with a flat base (Figure 1c) which are smaller than the other two species (length $=\sim 6 \mathrm{~mm}$ ).

Experiments were conducted with empty cases. Cases of $S$. personatum and P. latipennis were collected from Black Brook $\left(52^{\circ} 46^{\prime} 33.4^{\prime \prime} \mathrm{N} 1^{\circ} 17^{\prime} 57.6^{\prime \prime} \mathrm{W}\right)$ on $17^{\text {th }}$ June 2019 and preserved in $70 \%$ industrial methylated spirit (IMS). S. personatum and P. latipennis larvae were removed from their cases after preservation. Glossosomatidae larvae are more difficult to remove from their cases when preserved, so A. fuscipes larvae were collected on 18th August 2019 (Burleigh Brook, 52 $45^{\prime} 47.5^{\prime \prime} \mathrm{N} 1^{\circ} 14^{\prime} 32.8^{\prime \prime} \mathrm{W}$ ), and whilst alive, were gently removed from their cases using tweezers. Prior to experiments, all cases were soaked in deionized water to remove IMS and any air trapped within the case. Both collection streams were located in the East Midlands UK and were similar in size (1-3 m width; <0.2 m deep in riffles), hydraulic, and sediment characteristics. All larvae were selected to be late instar larvae with cases of similar sizes (within a species) as case design and entrainment thresholds may vary with larvae age, and therefore we limited our experiments to the final case form. Entrainment experiments were conducted between 20th August and 20th September 2019.

\subsection{Laboratory Flume Setup}

Entrainment experiments were conducted in a $10 \mathrm{~m}$ long, $0.3 \mathrm{~m}$ wide, Armfield S6 flume, with glass sidewalls (Figure $2 \mathrm{a})$. A raised bed of fixed gravel $\left(\mathrm{D}_{50}=15 \mathrm{~mm}\right) 0.08 \mathrm{~m}$ high was constructed along the entire flume length. 

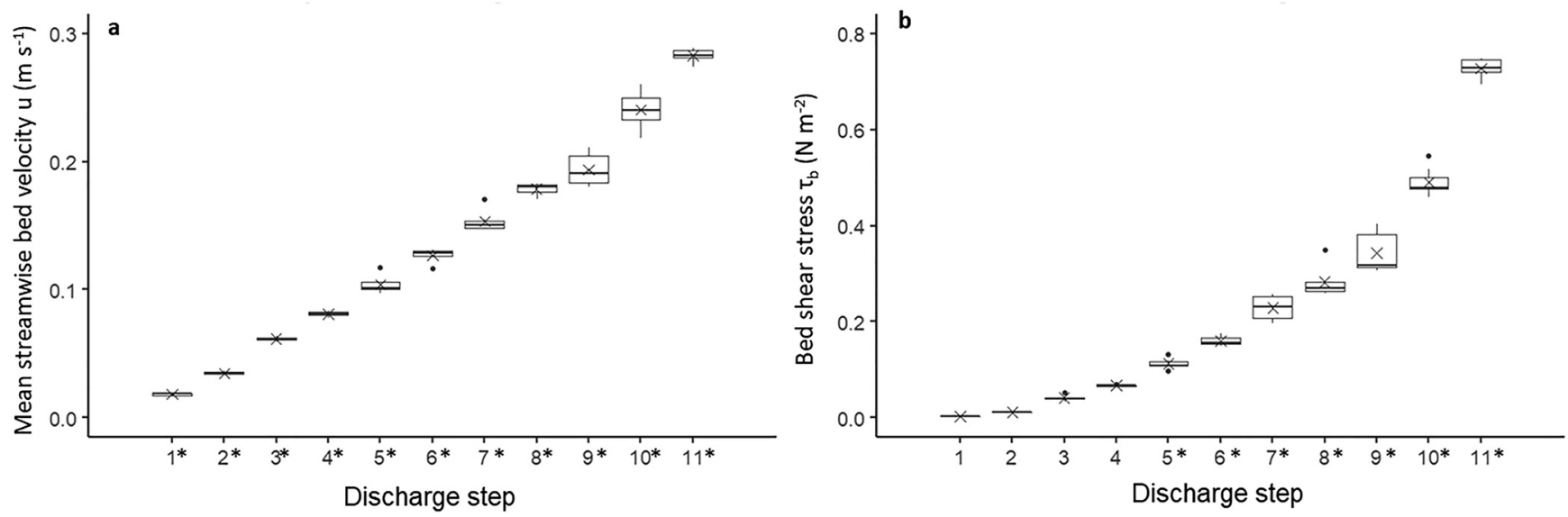

Figure 3. Hydraulic conditions during successive discharge steps 1-11 with increasing flow velocity and bed shear stress. (a) Mean near-bed velocity increases linearly with discharge step (b) Bed shear stress increases exponentially with discharge step. * indicates that the interval was significantly different from both of the neighboring discharge steps according to a Tukey Honest Significant difference test (adjusted $p<0.05$ ). Boxes show the median and interquartile range, whiskers show the range excluding outliers (points) and the mean is indicated by $x$.

Experiments were conducted $7 \mathrm{~m}$ from the flume inflow. A flat circular platform $(0.065 \mathrm{~m}$ in diameter $)$ was fixed to the bed so that its surface was $0.1 \mathrm{~m}$ from the flume base (thus approximately level with the upper surfaces of large particles $\left[\mathrm{D}_{90}\right]$ on the flume bed; Figure $2 \mathrm{~b}$ ). The flat platform improved observations of entrainment and ensured that the hydraulics were comparable between runs. A flume-spanning sediment trap was located $0.6 \mathrm{~m}$ downstream of this platform (depth $0.065 \mathrm{~m}$, length $0.18 \mathrm{~m}$ ) to collect entrained material (Figure $2 \mathrm{~b}$ ).

Eleven discharge steps with increasing flow velocity $(\mathrm{U})$ and bed shear stress $\left(\tau_{b}\right)$ were determined a-priori (Figure 3; Table S1 in Supporting Information S1). Discharge steps were used which covered the full range of critical entrainment thresholds for both cases and incorporated loose sediment with sufficient detail to capture differences in entrainment. Pump discharge was increased between each discharge step, and the tail gate and slope were adjusted to maintain a constant depth of $0.08 \mathrm{~m}$ over the test area. Measurements of discharge step hydraulics were taken during flow measurement runs, rather than during the entrainment experiments. At least five replicate flow measurement runs were conducted for calculation of bed shear stress (for most discharge steps $n=6$ ). This provided an estimate of the variability in flow conditions within and between discharge steps (Figure 3). A side facing Nortek $10 \mathrm{MHz}$ Acoustic Doppler Velocimeter was used to simultaneously measure the three orthogonal components of water velocity in the center of the experimental platform (Figure 2b). Velocity measurements were recorded for $120 \mathrm{~s}$ at a sampling frequency of $50 \mathrm{~Hz}$. The cylindrical volume over which velocity measurements were taken was $6 \mathrm{~mm}$ in height and centered $10 \mathrm{~mm}$ above the bed; thus velocity was measured between 7-13 $\mathrm{mm}$ above the bed (Nortek, 2009). The horizontal length of the measured area (measurement length) was adjusted to increase data quality but for most runs was $7 \mathrm{~mm}$. These velocity measurements were used to determine near bed velocity and bed shear stress using the turbulent kinetic energy approach (Biron et al., 2004) for each discharge step (details in Text S1 in Supporting Information S1). An additional velocity measurement, taken at $60 \%$ depth, was used to estimate depth averaged velocity $(n=3)$.

\subsection{Entrainment Procedure}

A single case was added to the center of the measurement platform during discharge step 1 (mean water velocity $=0.02 \mathrm{~m} \mathrm{~s}^{-1}$, Figure 3a). Case orientation is believed to be important for entrainment (e.g., Waringer, 1993), therefore cases were orientated facing upstream (Figure 4a). Each discharge step was maintained for $270 \mathrm{~s}$, after which the discharge was increased and the tail gate and slope adjusted to maintain stable flow conditions. This changeover process was completed in $30 \mathrm{~s}$ so that each discharge step took five minutes. A video camera positioned above the measurement area was used to record entrainment and still photographs of the measurement platform were taken $240 \mathrm{~s}$ after the start of each discharge step (i.e., immediately prior to adjusting the flume setup for the next interval) to estimate sediment remaining on the platform during each discharge step. 

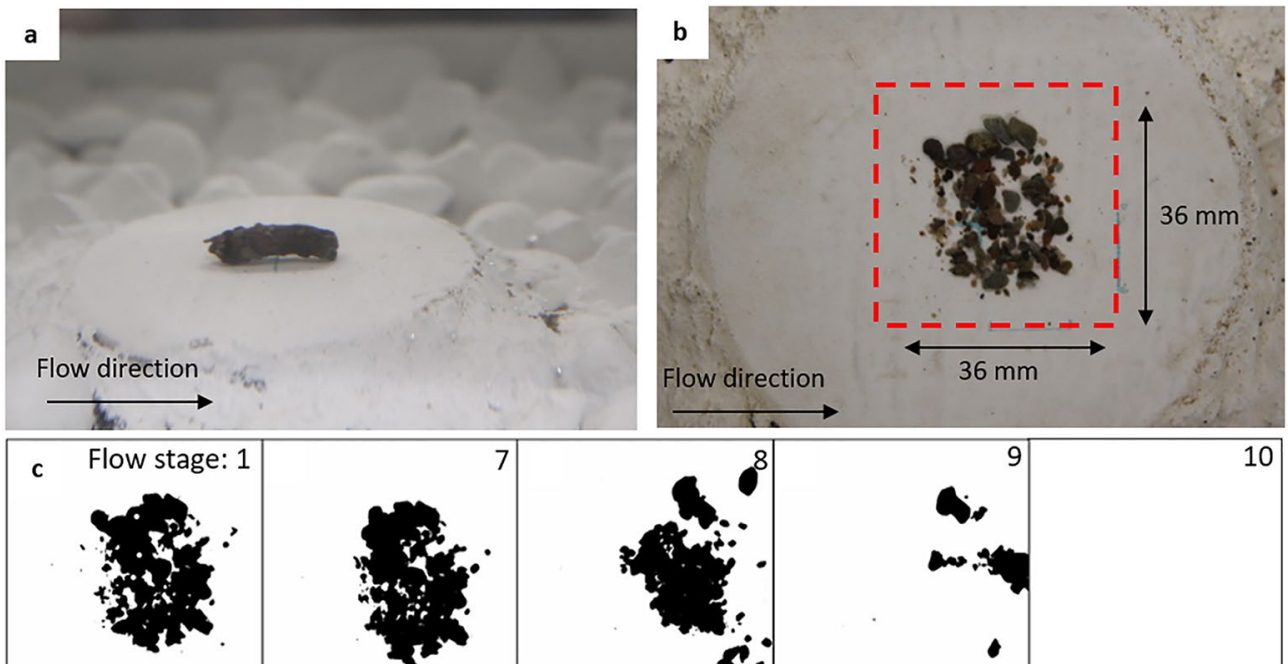

Area lost: $0 \%$
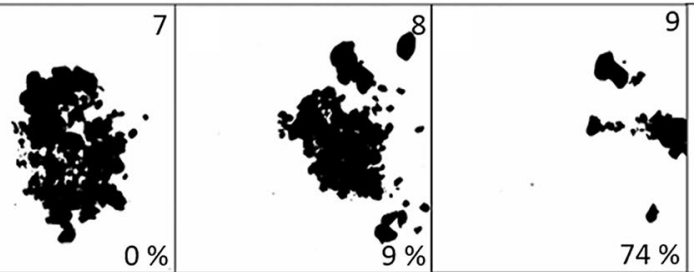

Figure 4. Entrainment of cases and loose sediment from the measurement platform. (a) Potamophylax latipennis case position during the first discharge step. (b) P. latipennis loose sediment during the first discharge step. For both cases and loose sediment an area $36 \times 36 \mathrm{~mm}$ (marked outline) was defined to help classify sediment movement. (c) Image analysis was used to remove subjectivity from the classification of entrainment thresholds for loose sediment runs (conducted in Image J; Abramoff et al., 2004). The surface area of particles mobilised during each discharge step was calculated as a percentage of the initial area of loose sediment.

Eight cases were tested for each species and each was used only once. Cases were then disaggregated into their constituent sediment grains (hereafter loose sediment) and the same entrainment procedure applied to loose sediment (total 48 flume entrainment experiments, 8 replicates of 3 species for both cases and loose sediment). Cases were dried at $70^{\circ} \mathrm{C}$ for $3 \mathrm{hr}$ and weighed. To disaggregate cases $30 \%$ hydrogen peroxide $\left(\mathrm{H}_{2} \mathrm{O}_{2}\right)$ was added at $80^{\circ} \mathrm{C}$ and cases were stirred to facilitate the breakdown of silk (following Mason et al., 2019). The remaining case sediment was washed through a $0.063 \mathrm{~mm}$ sieve and dried. The sediment for each case was individually sieved through $38 \mathrm{~mm}$ diameter sieves at half phi intervals to determine the particle size distribution. Despite the low masses of sediment involved, mean mass loss during sieving was only $0.7 \%$ per case.

After soaking in deionized water, loose sediment was added to the flume through a small funnel, which prevented entrainment of fine grains before the experiment began. Loose sediment was spread over an approximately circular patch, 1 grain thick in the center of the measurement platform (Figure 4b).

\section{Data Analysis}

\subsection{Discharge Steps}

Near-bed flow velocity increased approximately linearly and $\tau_{b}$ exponentially with discharge step (Figure 3). A Tukey Honest Significance Difference test demonstrated that all discharge steps were significantly different from both neighboring discharge steps with respect to near bed flow velocity and steps 5 upwards were significantly different for $\tau_{b}$ (adjusted $p<0.05$ ). For further analysis the mean $\tau_{b}$ for each discharge step was used. Statistics were conducted in the stats package for R Studio (version 3.5.1, R Core Team, 2018).

\subsection{Entrainment and Mobility Thresholds}

Estimating sediment entrainment thresholds is often subjective, making it difficult to make comparisons between studies (Perret et al., 2015; Vanoni, 2006). We used an image analysis technique to measure sediment entrained during each discharge step using ImageJ (Abramoff et al., 2004; Figure 4c). Photographs of the experimental area were scaled and thresholded to identify sediment particles from the white background (Figure 4c). Images were cropped to a $36 \times 36 \mathrm{~mm}$ square, centered on the measurement platform, which was used to differentiate between 
Table 1

Size and Shape Characteristics for Cases and Loose Sediment

\begin{tabular}{|c|c|c|c|c|c|c|c|}
\hline & & $\mathrm{a}(\mathrm{mm})$ & $\begin{array}{c}\mathrm{b} \text { or } \mathrm{D}_{50} \\
(\mathrm{~mm})\end{array}$ & $\mathrm{c}^{*}(\mathrm{~mm})$ & $\mathrm{Vc}\left(\mathrm{mm}^{3}\right)$ & $\mathrm{m}_{\mathrm{c}}(\mathrm{g})$ & $\rho_{\mathrm{e}}\left(\mathrm{g} \mathrm{cm}^{-3}\right)$ \\
\hline \multirow[t]{3}{*}{ Case } & S. personatum & $14.57(0.66)$ & $3.07(0.11)$ & $3.01(0.11)$ & $107.89(21.73)$ & $0.03(0.004)$ & $1.16(0.02)$ \\
\hline & P. latipennis & $21.75(0.86)$ & $5.73(0.42)$ & $4.84(0.37)$ & $565.97(110.33)$ & $0.26(0.04)$ & $1.28(0.03)$ \\
\hline & A. fuscipes & $6.01(0.32)$ & $3.63(0.59)$ & $2.34(0.11)$ & 67.67 (16.75) & $0.03(0.01)$ & $1.29(0.05)$ \\
\hline \multirow[t]{3}{*}{ Loose sediment } & S. personatum & & $0.27(0.02)$ & & & & \\
\hline & P. latipennis & & $1.16(0.15)$ & & & & \\
\hline & A. fuscipes & & $0.98(0.2)$ & & & & \\
\hline
\end{tabular}

Note. Mean with standard deviation in brackets. a, b, and c indicate major, intermediate and minor particle axes respectively. $\mathrm{D}_{50}$ reported as $\mathrm{b}$ axis for loose sediment. Volume $\mathrm{Vc}$, mass $\mathrm{m}_{\mathrm{c}}$, and effective density $\rho_{\mathrm{e}}$, reported for cases. *Case minor axes (c) were estimated from a seperate sample (see text).

remaining sediment and mobilised sediment. Thus, cases and individual loose sediment grains were on average required to move $>18 \mathrm{~mm}$ (approximately the longest case length of the three species; $P$. latipennis) to classify as mobilised (36 mm/2; Figure 4b). The surface area of loose sediment was used as an estimate of the sediment remaining. The percentage difference between the area of sediment in the initial image (discharge step 1) and each subsequent discharge step was calculated (Figure 4c). This gave a quantitative estimate of cumulative sediment entrained during each discharge step.

In the analysis we consider the effects of case construction and species on two bed shear stress thresholds: (a) critical entrainment $\left(\tau_{c}\right)$ and (b) $90 \%$ sediment moved $\left(\tau_{90}\right)$. Cases moved as one particle, so there is no difference between these thresholds for cases. However, for loose sediment, we used the discharge step during which $10 \%$ sediment area had been entrained as critical entrainment $\left(\tau_{10}\right)$ and $90 \%$ sediment entrained as equivalent to general movement ( $\tau_{90}$; Perret et al., 2015; Petit, 1994). A more detailed analysis was conducted for the $\tau_{90}$ threshold because this better represents the overall mobility of sediment than critical entrainment.

Mobility threshold data for cases and loose sediment of each species were mostly non-normal (Shapiro-Wilk $p<0.05$ for all except $A$. fuscipes cases), therefore, non-parametric statistics were used. Wilcoxon signed-rank tests were used with a Bonferroni adjustment to examine whether a significant difference existed between the entrainment and mobility thresholds of cases $\left(\tau_{c}\right.$ and $\left.\tau_{90}\right)$ and their constituent loose sediment (paired data).

\subsection{Importance of Case Design}

To determine if a significant difference existed between species, for either case or loose sediment entrainment, a Kruskal-Wallis test was conducted followed by post-hoc Mann-Whitney (Wilcoxon rank sum) tests with a Bonferroni adjustment. Subsequently, to understand the importance of case design; $\tau_{90}$ values were divided by case mass $\tau_{90} / m_{c}$. If differences in mobility between cases still exist, they can therefore be attributed to case shape or associated variables. As for entrainment threshold data, Kruskal Wallis followed by Wilcoxon rank sum tests, with a Bonferroni adjustment, were then conducted for differences between species for $\tau_{90} / m_{c}$. Spearman's rank correlations were used to consider the association between case mass and entrainment independently for each species.

To investigate differences in case shape, the length and width ( $\mathrm{a}$ and $\mathrm{b}$ axis respectively) of each case used in the flume experiments were measured using a photograph taken against a backlit background and later analyzed in ImageJ. A separate sample of cases collected from the same site on the same date as those used in the flume experiments were measured for all three axes, using electronic Vernier calipers (checked with a microscope eyepiece graticule and stage micrometer). A linear association between the $\mathrm{b}$ and $\mathrm{c}$ axis (case height) of each species was then used to estimate the $\mathrm{c}$ axis for the cases used in the flume experiment $\left(\mathrm{R}^{2}\right.$ values for $S$. personatum $=0.99$ $(n=8)$, P. latipennis $=0.64(n=8)$, A. fuscipes $=0.15(n=16)$; Figure S1 in Supporting Information S1). The low $\mathrm{R}^{2}$ between $\mathrm{b}$ and $\mathrm{c}$ axes for $A$. fuscipes cases reflects natural variability in shape. The dimensions of cases 
of all three species were very different (Table 1) and the method provides a sufficiently accurate estimate of case-volume to differentiate between species.

Case volume of tubular cases (S. personatum and P. latipennis) was calculated as a cylinder according to Equation 1 and as an ellipsoid cap (Equation 2) for the dome shaped Glossosomatidae cases.

$$
\begin{gathered}
V c_{t}=\pi r^{2} a \\
V c_{d}=\pi a b\left(\frac{2 h}{3}-c+\frac{c^{3}}{3 h^{2}}\right)
\end{gathered}
$$

where, $V c_{t}$ is volume of tubular cases, $\mathrm{r}$ is radius (b axis/2), $V c_{d}$ is the volume of domed cases. As the height of the full ellipsoid of which the ellipsoid cap is a part was unknown, ellipsoid height $\mathrm{h}$ was taken as $2 * \mathrm{c}$ (i.e., $2 \mathrm{x}$ case height).

Effective density of cases $\rho_{e}$ was then calculated according to:

$$
\rho_{e}=\frac{m_{t}}{V c}
$$

where $V c$ is the total case volume (estimated in Equations 1 and 2) and $m_{t}$ total mass was calculated according to:

$$
m_{t}=m_{c}+m_{w}
$$

where $m_{c}$ is case mass (Table 1$)$ and $m_{w}$ is the mass of water contained within the case estimated according to:

$$
m_{w}=\rho_{w} V_{w}
$$

where $\rho_{w}$ is water density $=1,000 \mathrm{~kg} \mathrm{~m}^{-3}$ and $V_{w}$ the volume of water contained within the case:

$$
V_{w}=V_{s}-V c
$$

where:

$$
V_{s}=\frac{m_{c}}{\rho_{s}}
$$

where $\rho_{s}$ is sediment density $=2,650 \mathrm{~kg} \mathrm{~m}^{-3}$.

The Shields diagram (Shields, 1936) provides a useful means to compare the effects of different organisms on critical entrainment thresholds (following Mason \& Sanders, 2021) and is commonly used to non-dimensionalize entrainment thresholds (Yang et al., 2019). Shields parameter $\left(\tau_{* c}\right)$ was calculated according to Equation 8, for cases and loose sediment of each species:

$$
\tau_{* c}=\frac{\tau_{c}}{\left(\rho_{s}-\rho_{w}\right) \mathrm{gD}}
$$

where $\tau_{c}$ is bed shear stress during the discharge step at which critical entrainment occurred (i.e., $10 \%$ of sediment moved), $\rho_{s}=2,650 \mathrm{~kg} \mathrm{~m}^{-3}$ for loose sediment and effective density $\rho_{e}$ for cases and $\mathrm{g}$ is acceleration due to gravity $=9.81 \mathrm{~m} \mathrm{~s}^{-2}$. $\mathrm{D}$ is a characteristic particle diameter; for loose sediment this is $\mathrm{D}_{50}$ and for cases the a axis (case length). This was plotted against grain Reynolds number ( $R e_{*}$ Equation 9$)$ to compare case and loose sediment entrainment thresholds to the curve developed by Shields (1936).

$$
R e_{*}=\frac{u_{*} \mathrm{D}}{\mathrm{v}}
$$

where $u_{*}$ is the shear velocity (Equation 10) and $\mathrm{v}$, water kinematic viscosity $=1 \times 10^{-6} \mathrm{~m}^{2} \mathrm{~s}^{-1}$.

$$
u_{*}=\sqrt{\frac{\tau_{10}}{\rho_{w}}}
$$




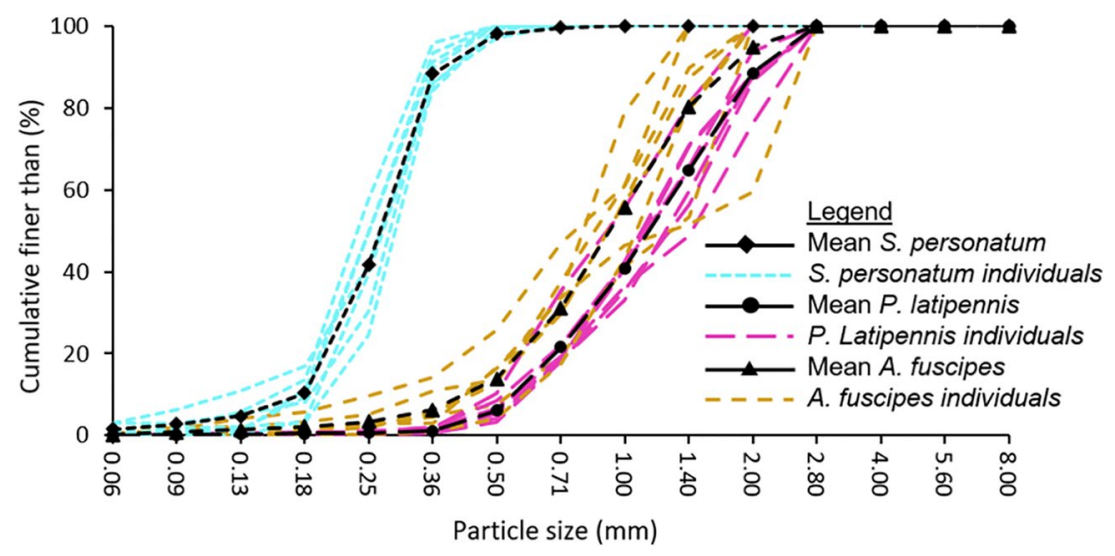

Figure 5. Cumulative particle size distribution for case sediment of each of the three species. Mean indicated by line with markers. Particle size indicates passing sieve.

\section{Results}

\subsection{Entrainment of Cases Versus Constituent Loose Sediment}

The construction of cases by caddisfly larvae results in composite particles which are much larger than the constituent loose sediment (Table 1). S. personatum used the finest sediment (mean $\mathrm{D}_{50}=0.27 \mathrm{~mm}$ ), converting this to a case of mean width (b axis) of $3.07 \mathrm{~mm}$ and length $14.57 \mathrm{~mm}$. P. latipennis and A. fuscipes used coarser sand particles with similar size distributions (mean $\mathrm{D}_{50}=1.16$ and $0.98 \mathrm{~mm}$ respectively; Figure 5) but $P$. latipennis cases were considerably larger and had greater mass than both of the other species (Table 1).

Comparing both critical entrainment $\left(\tau_{\mathrm{c}}\right)$ and general movement $\left(\tau_{90}\right)$ of cases and loose sediment, both $S$. personatum and P. latipennis cases moved at significantly lower critical shear stress thresholds than their loose case sediment (Figures $6 \mathrm{a}$ and $6 \mathrm{~b}$ ). All cases of $S$. personatum or $P$. latipennis were entrained below the shear stress required to entrain their respective sediment grains. In contrast, critical entrainment of $A$. fuscipes cases occurred at higher shear stress than loose sediment (Figure 6c) but generally cases moved over a similar range of $\tau_{\mathrm{b}}$ as their constituent sediment, and there was no significant difference between cases and loose sediment for general entrainment, $\tau_{90}$ (Figure 6c). Caddisfly case construction also decreases the Shields criterion of transported sediment and increases effective particle size (Figure 7). As a result, cases of all species were moved at $\tau_{* c}$ far below that expected for the size of these particles (Figure 7).

\subsection{Differences in Mobility Between Species}

The shear stress required to entrain cases was significantly different between each species (Figure 8a). S. personatum moved under the lowest shear stress (mean $\tau_{\mathrm{c}}=0.06 \mathrm{~N} \mathrm{~m}^{-2}$ ). P. latipennis required $0.18 \mathrm{~N} \mathrm{~m}^{-2}$ to move and $A$. fuscipes required the greatest shear stress to entrain (mean $\tau_{\mathrm{c}}=0.28 \mathrm{~N} \mathrm{~m}^{-2}$ ). Qualitative observation of the method of movement for cases indicated variability between species. As shear stress increased, tubular cases (S. personatum and P. latipennis): (a) rocked in situ, (b) spun so that they were transverse to the flow and, (c) rolled off the measurement area (Movie S1). In contrast, A. fuscipes initially moved by sliding followed by either continued sliding or, occasionally, by rolling.

Unlike cases which moved as one particle, loose sediment particles moved over a much wider range of $\tau_{\mathrm{b}}$ (Figure 6). For example, transport of $S$. personatum sediment was initiated as early as $0.11 \mathrm{~N} \mathrm{~m}^{-2}$ but reached the $90 \%$ threshold at $0.34 \mathrm{~N} \mathrm{~m}^{-2}$ (Figure 6a). P. latipennis loose sediment required greater shear stresses to entrain than the sediment from the other two species cases (Figure 6).

Determining the method of movement for loose sediment was considerably harder than for cases and many particles were too small to observe. Larger particles of sediment of all species moved by a mixture of rolling and sliding (dependant on the sphericity of the particle). Loose sediment also showed signs of grain interactions, with sediment patches moving together and areas of smaller grains building up behind larger grains. This was 

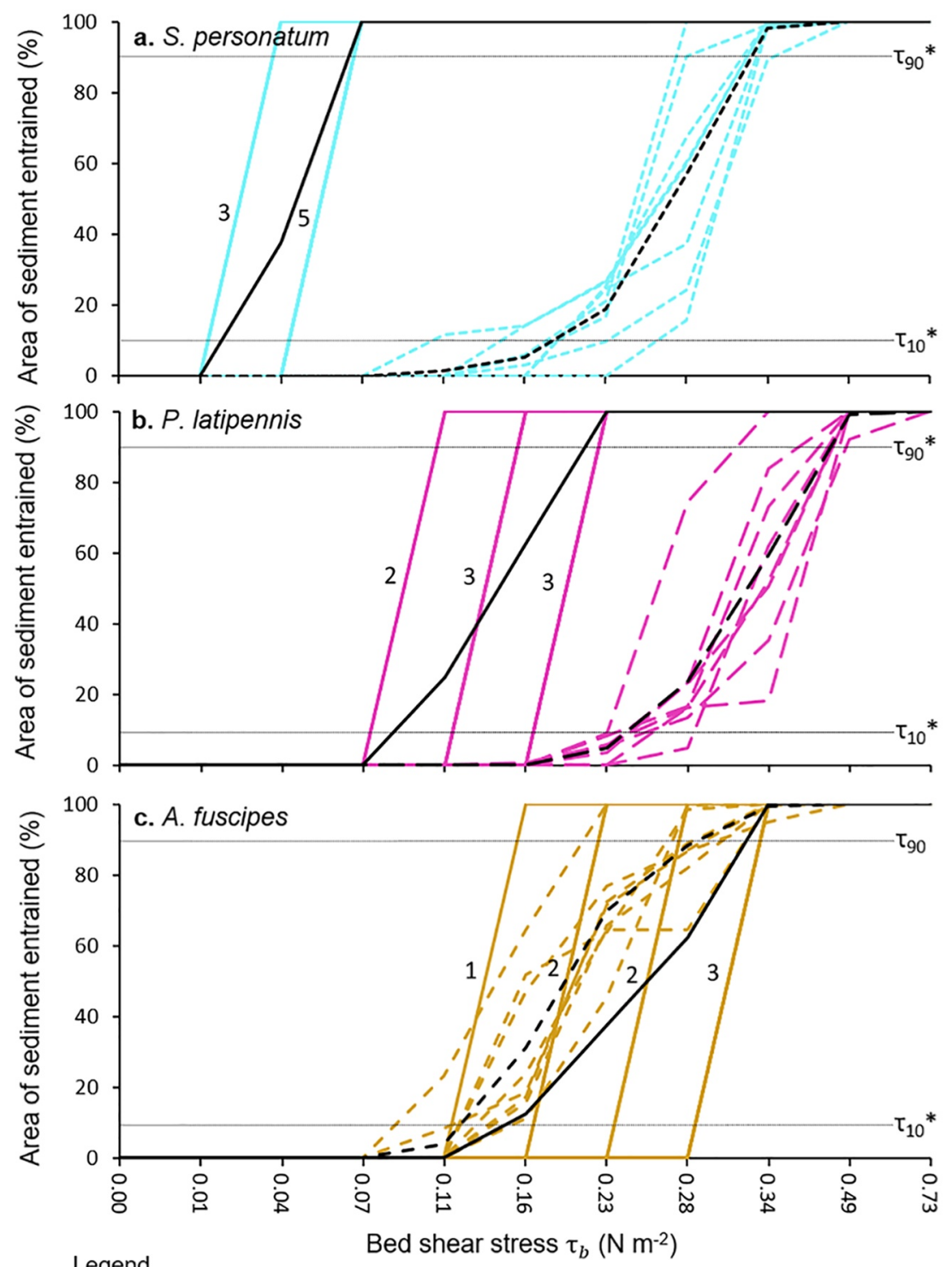

Legend

Mean of each taxa's case entrainment

_ _ _ - Mean of each taxa's sediment entrainment

- -- S. Personatum case/ sediment

- - P. Latipennis case/ sediment

- - A. Fuscipes case/ sediment

Figure 6. Percent of sediment entrained by the end of each discharge step for cases (solid line) and loose sediment (dashed line) of each species $(\mathrm{a}-\mathrm{c}) . X$ axis shows bed shear stress during each discharge step (Figure 3 ). Numbers adjacent to each solid line (cases) indicate the number of repeats at that value. Critical entrainment $\tau_{10}$ and general movement $\tau_{90}$ thresholds included with significant differences between mobility thresholds for cases and loose sediment $(p<0.05)$ indicated by *

particularly evident for A. fuscipes and P. latipennis, which comprise a greater range of particle sizes than $S$. personatum (Figure 5).

\subsection{Importance of Case Design}

The case designs of each species were different (Figure 1). P. latipennis built straight tubular cases with substantially greater mass and volume than the other two species (Table 1). S. personatum and A. fuscipes built cases of similar mass (both $0.03 \mathrm{~g}$; Table 1) but $S$. personatum cases were more than twice as long and slightly curved. Both $S$. personatum and P. latipennis have $\mathrm{b}$ and $\mathrm{c}$ axis dimensions which were far exceeded by the a axis, and 


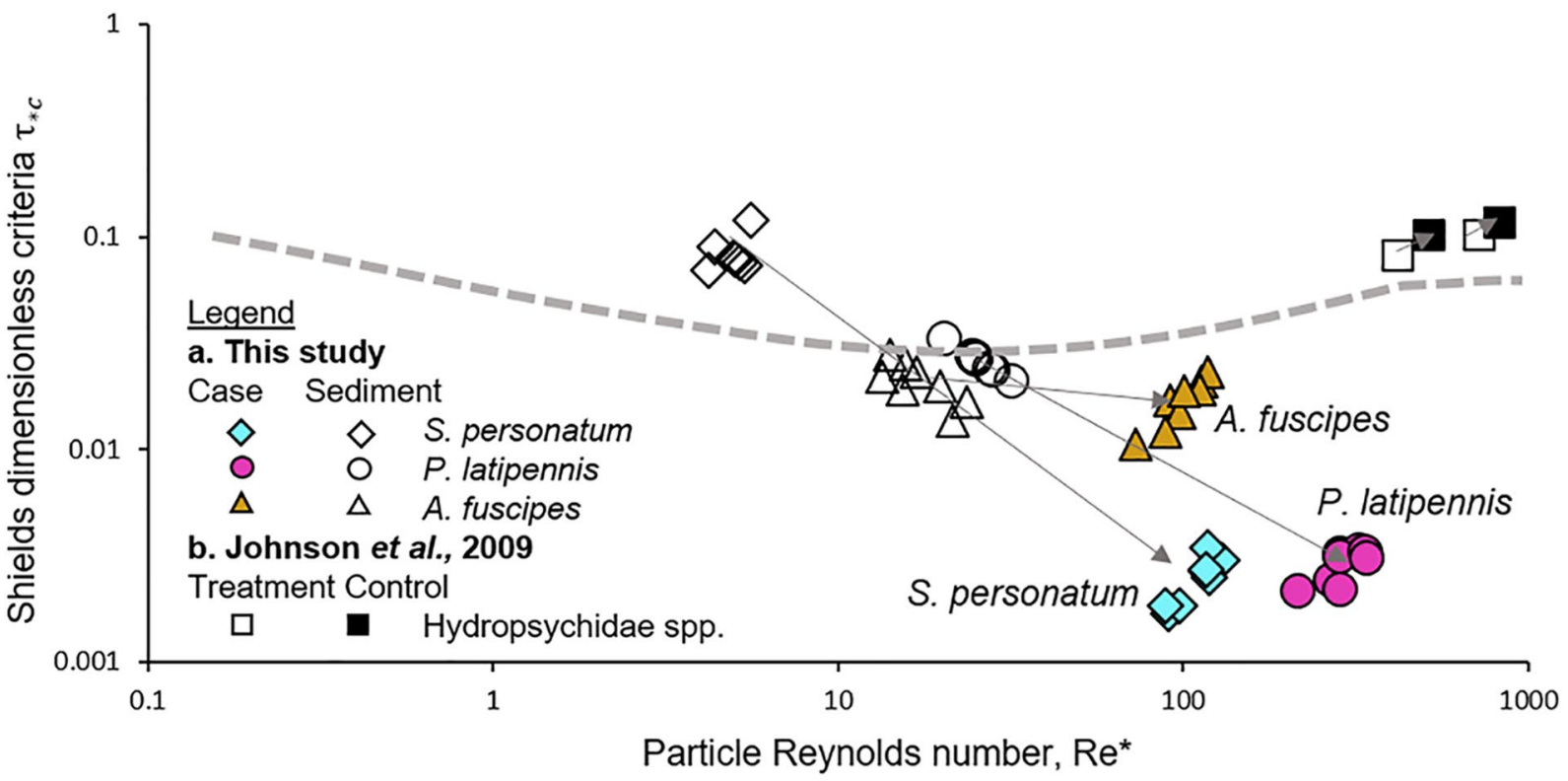

Figure 7. Effects of (a) case construction and (b) net constructions (from Johnson et al., 2009), by caddisfly larvae on the critical Shields criteria. For case construction, loose sediment plots closer to the Shields line, which indicates critical entrainment thresholds for sediment grains across a gradient of particle size and density (based on the empirical work of Shields, 1936). Sediment in caddisfly cases of all species was entrained at $\tau_{* c}$ below that expected for the size of these particles. Arrows indicate approximate change in the Shields parameter and Reynolds number which occurs due to case construction by caddisfly larvae. Previous work has shown that caddisfly filter feeding nets increase critical entrainment thresholds (e.g., Johnson et al., 2009) but this is the first study to show caddisfly can reduce entrainment thresholds via case construction.

were both therefore rod shaped according to Sneed and Folk's (1958) classification (Figure S2 in Supporting Information S1). S. personatum cases had a circular cross section while $P$. latipennis cases were roughly oval. A. fuscipes cases were elongated hemispheres with a flat base and sharp angles between the base and sides (Figure S2 in Supporting Information S1).

After dividing by mass $\left(\tau_{90} / m_{c}\right)$ P. latipennis cases were transported at significantly lower shear stress than $S$. personatum cases (Figure $8 b$ ). This suggests that differences in mass are largely responsible for the significantly higher entrainment threshold of $P$. latipennis than $S$. personatum cases (Figure 8). After controlling for mass, A. fuscipes cases still required significantly greater shear stress to entrain than the other case types (Figure $8 \mathrm{~b}$ ). This suggests that shape, not mass, was largely responsible for the difference between dome shaped A. fuscipes and the tubular cases of the other species.

Considering differences in entrainment between cases of the same species (Figure 9), there is a significant association between the mass of each P. latipennis case and $\tau_{\mathrm{c} \text {, }}$ suggesting that mass is an important control on entrainment for this species (Figure 9b). This association is not present for S. personatum (Figure 9a) or A. fuscipes cases (Figure 9c). Consequently, whilst shape appears to explain the difference in entrainment between $P$. latipennis and $A$. fuscipes cases (Figure 8b), between individuals of $P$. latipennis, case mass may be important in determining entrainment thresholds.

\section{Discussion}

\subsection{Transport of Caddisfly Cases Versus Loose Sediment: Role of Case Mass, Size and Shape}

Sediment transport in rivers has received decades of research considering a wide range of sediment and hydraulic conditions, including sediment size, shape and sorting (e.g., Dietrich et al., 1989; Gomez \& Church, 1989; Powell, 1998). However, such studies have typically ignored the role of biology. We present the first study of how animal bioconstructions (as opposed to bioturbation) influence transport of directly incorporated sediment in rivers. Many caddisfly larvae create agglomerations of mineral sediment that have novel properties to the grains used in their construction, being hollow and effectively less dense. Caddisfly case construction therefore has important implications for sediment mobility and transport (Figure 6). 


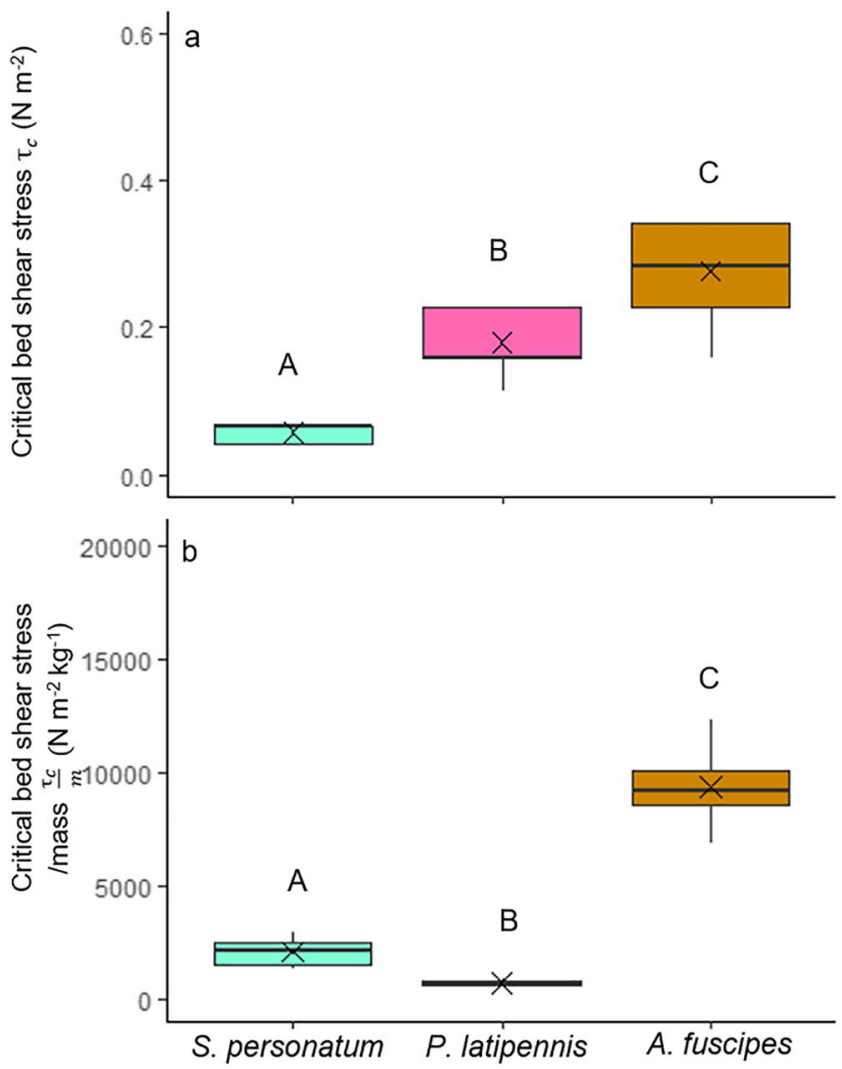

Figure 8. (a) Bed shear stress required to entrain cases of each species (b) Bed shear stress required to entrain cases of each species divided by the mass of that case. Significance shown by letters, with different letters indicating significant differences between species, $p<0.05$. Boxes show the median and interquartile range, whiskers show the range excluding outliers and the mean is indicated by $x$.
Mean flow velocity increases rapidly with distance above the riverbed and therefore larger particles experience greater drag. For mineral sediment grains, this increased exposure is usually offset by an increase in particle mass, meaning that, at least in simple bed settings, larger particles require higher shear stresses to entrain them (Shields, 1936 et seq; Figure 7). However, whilst caddisfly cases have substantially greater mass than the individual sand grains incorporated, they are also hollow, and therefore have lower effective density relative to a solid mineral particle (Table 1 ). S. personatum and $P$. latipennis both constructed large tubular cases which were easier to entrain than their loose constituent sediment (Figures 6a and 6b), suggesting that their increased exposure to shear stress due to protrusion, outweighed the increase in mass resulting from the cementing of many small sediment grains together.

Whilst $S$. personatum and P. latipennis cases were both tubular they differed considerably in mass, resulting in the heavier $P$. latipennis cases being much less mobile (Figure 6b). A. fuscipes larvae built cases that had similar mass to $S$. personatum and were considerably lighter than P. latipennis. However, A. fuscipes cases were much harder to entrain than either of the other species (Figure 8). The shape of $A$. fuscipes cases was very different to cases of $S$. personatum and $P$. latipennis, resembling domes over a flat base rather than tubes (Figures 1 and S2 in Supporting Information S1). The tubular shape and rounded profile of $S$. personatum and $P$. latipennis meant that once turned perpendicular to the flow they rolled easily off the measurement platform (Movie S1). In contrast, the flat base of A. fuscipes probably increased friction, prevented rolling, and therefore required much greater shear stress for entrainment.

\subsection{Implications of Results for Gravel-Bed Rivers}

The simplicity of the experiment allowed for the considerable levels of control necessary to reveal subtle differences in entrainment thresholds between cases of species with different designs and between loose sediment and caddisfly bioconstructions. However, the simplicity also has a number of limitations for the wider extrapolation of the results to rivers. Entrainment
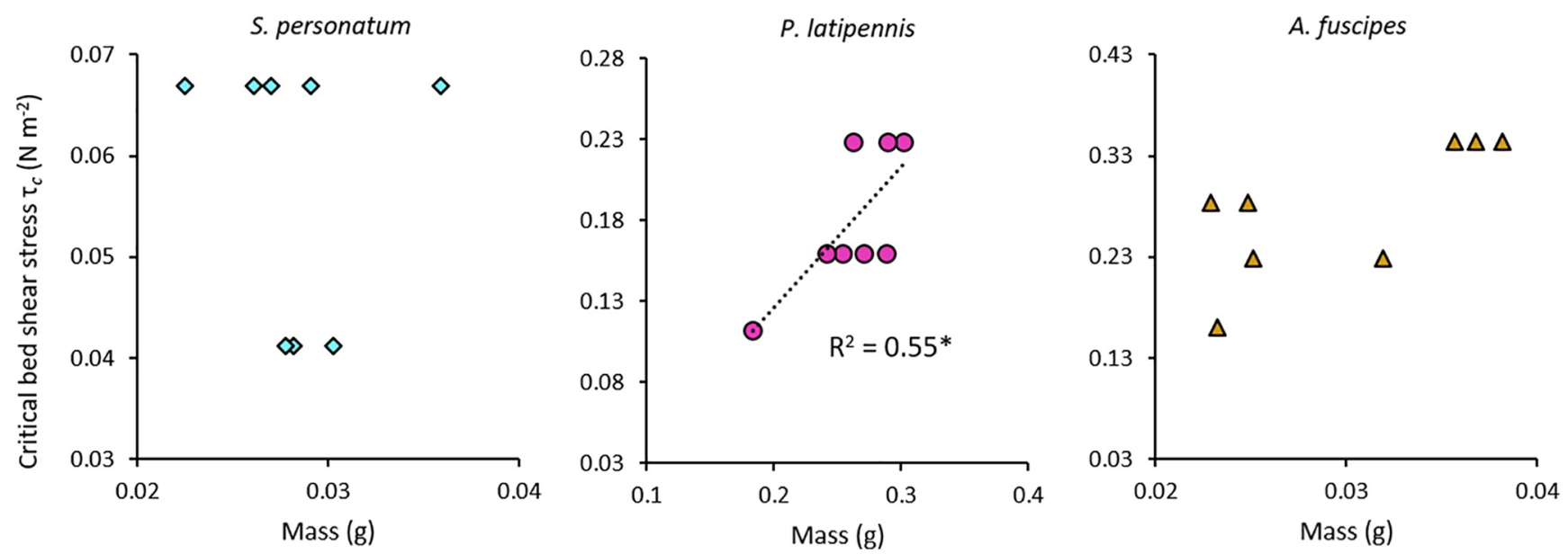

Figure 9. Associations between case mass and critical bed shear stress for each species. Only P. latipennis showed a significant trend (* indicates significance where $p<0.05)$. 
was measured from a flat platform (Figure 2) and therefore did not consider the transport of cases and loose sediment over a rough gravel-bed or consider the influence of behavior of caddisfly inhabitants on sediment transport.

\subsubsection{Transport of Caddisfly Cases Over Gravel River Beds}

Whilst hydraulic conditions in the flume were fully turbulent, characteristic of gravel-bed rivers, the bed topography from which cases and sediment were transported was simplified to a flat plate. This allowed for direct comparison of entrainment thresholds between treatments, without the complications inherent in transport over a gravel surface and facilitated detailed observation and quantification of sediment transport (Figure 4). Qualitative observations of case entrainment showed that, once entrained, cases and loose sediment quickly came to rest in the first sheltered pocket between gravel particles that they encountered. Therefore, entrainment thresholds of both cases and loose sediment will be considerably higher from within gravel pockets due to the shelter they provide and the geometry of the pocket requiring the particles to move upwards to escape (Powell, 1998).

We expect that the difference in entrainment between caddisfly cases and fine sediment found on a flat plate in this experiment will be increased over a gravel surface. This is because; (a) cases are effectively less dense and are therefore more easily transported out of sheltered pockets. (b) cases are larger than their constituent sand grains and are therefore less likely to find sheltered pockets, resulting in overpassing (sensu Carling, 1990; Isla, 1993), and if resting in a pocket, are more likely to protrude out of the pocket, reducing their entrainment thresholds. Furthermore, larger particles (relative to pocket forming grains) have lower pivot angles, increasing likelihood of entrainment from pockets (Komar \& $\mathrm{Li}, 1986$ ). (c) Cases have high rollability and the near spherical cross section of S. personatum and P. latipennis cases increases their ability to roll out of these pockets, likely reducing their entrainment thresholds (e.g., Demir, 2000). In addition, rod shaped particles are particularly mobile, because they can twist around obstacles and are less likely to find pockets in bed topography where they are stable (Demir, 2000).

As a consequence, it is probable that due to their size and shape, S. personatum and P. latipennis cases will be transported at lower shear stresses over gravel beds in rivers than their constituent sediment because of their shape and density. Nevertheless, further research is required to quantify the transport of caddisfly cases over rough and mobile gravel-beds and in more complex field conditions. Differences in sediment grain properties can have substantial impacts on sediment entrainment (Demir, 2000; Powell, 1998) and this is particularly true for bioconstructions, which substantially modify particle shape, size and density.

In gravel-bed rivers grain interactions are important to sediment transport because imbrication, packing, sorting and hiding substantially modify the mobility of grains (e.g., Parker \& Sutherland, 1990). In our experiment, loose sediment was subject to grain interactions whilst cases were not. Consequently, particle interactions, including hiding of smaller grains by larger grains may be partly responsible for increasing the shear stress required to transport the loose sediment. Nevertheless, because both P. latipennis and S. personatum cases had been transported at shear stresses lower than that required for the initial movement of loose sediment (Figures 6a and 6b) we are confident that even without these grain interactions, loose sediment requires greater bed shear stress to transport than tubular caddisfly cases.

\subsubsection{Live Larvae Behavior}

Understanding animal behavior and how this affects sediment dynamics is a challenge for zoogeomorphology. This experiment took the first step toward understanding how case constructions affect the mobility of the incorporated sediment, considering caddisfly cases without their larval occupants. Organism behavior varies at the species and individual level, and the simplistic flume setup required for accurate determination of entrainment thresholds was unsuitable for considering live larvae. Experimental trials with live larvae under low flow velocities resulted in larvae walking downstream (probably as the quickest way to escape their unnatural environment) and in higher flows clinging to the flume edges where velocities were reduced.

It is anticipated that the presence of live caddisfly larvae would increase the resistance of the case to entrainment. Live larvae are able to actively reduce drift by gripping substrate, changing case orientation (e.g., facing into flow to reduce exposure) and moving to avoid areas of high flow exposure (Rice et al., 2007; Waringer, 1989). Caddisfly larvae may also be able to sense increasing shear stresses and seek refuge pre-emptively to avoid entrainment (Townsend \& Hildrew, 1994). 
Active resistance to entrainment varies between species; for Potamophylax cingulatus, a closely related species to P. latipennis considered in this study, larvae were able to resist entrainment up to flow velocities of approximately $1.15 \mathrm{~m} \mathrm{~s}^{-1}$ (Otto, 1976), far greater than the maximum near bed flow velocity we considered $\left(0.28 \mathrm{~m} \mathrm{~s}^{-1}\right.$; Figure 3$)$. Allogamus auricollis build a case of coarse sediment grains, akin to P. latipennis (Kiauta \& Kiauta, 1979). For A. auricollis active resistance accounted for 55\% of current resistance (Waringer, 1989). Similarly, Otto and Johansson (1995) found that cases of Silo spp. (Goeridae) caddisfly were entrained at $0.10 \mathrm{~m} \mathrm{~s}^{-1}$ (similar to $P$. latipennis in our experiment) but with the addition of a live larvae this increased to $0.64 \mathrm{~m} \mathrm{~s}^{-1}$. Together these studies suggest that, if similar results apply to $P$. latipennis when the live larvae is present, cases will be more difficult to erode than loose sediment. The presence of live A. fuscipes larvae is also likely to reduce entrainment of sediment because larvae can fix their case to substrate with silk (Olden et al., 2004). Thus, the zoogeomorphic effects of tubular case-building caddisfly may reverse after the larvae leaves or abandons the case. Consequently, further work is required to understand the role of caddisfly larvae behavior in the mobility of their case sediment.

\subsection{Implications for Understanding How Case Design Affects Function for Caddisfly Larvae}

This study suggests that caddisfly cases of different shapes provide different functions to the larvae occupants, reflecting their behavior and adaptation to the river environment. Whilst for all taxa a mineral case will provide some passive resistance to drift and reduce drift distance over a caseless larvae, domed cases appear particularly adept at reducing entrainment whilst tubular cases may reflect other priorities such as efficient crawling or burrowing. S. personatum burrow into the substrate (Wagner, 1990, 1991), a behavior which is almost certainly facilitated by the smooth external surface of S. personatum cases. Constructing a smooth case requires the use of many small grains, which have low mass, and therefore burrowing efficiency may come at the expense of lower flow resistance. Instead, burrowing may be used to avoid entrainment. In terms of critical shear stress per unit mass, $S$. personatum cases are harder to entrain than P. latipennis cases (Figure $8 \mathrm{~b}$ ). This suggests that some elements of the design of $S$. personatum cases may help to resist entrainment. For example, the slightly curved profile of S. personatum cases (Figure 1a) probably reduces rolling in comparison to an equivalent straight case, which may explain the curved design of these cases.

For each species' case we individually examined any association between case mass and critical shear stress. We found no association between S. personatum case mass and mobility (Figure 9a). Delgado and Carbonell (1997) found cases of Sericostoma selysi (morphologically similar to $S$. personatum cases) from high velocity river sections were larger and had greater mass than those from sections with lower flow velocity and suggest this is an adaptation to reduce drift. Our results suggest that for S. personatum, the greater mass of a larger case may be offset by an increase in mobility due to extra protrusion into the flow. However, because individuals were selected to be similar in size and gathered from a single habitat, the range of case masses considered is very narrow (Figure 9). Larger differences in case mass and design arising from different hydraulic conditions may reveal interesting associations with entrainment. For $P$. latipennis, the relatively heavy case reduces the energy the larvae needs to use to actively resist entrainment. $P$ latipennis are usually found on the bed surface but hide in interstices rather than residing on exposed particles as is the case for Glossosomatidae. Cases of $P$. latipennis showed a positive correlation between case mass and critical entrainment shear stress (Figure 9b). Thus, building a case of greater mass may help the larvae to reduce entrainment.

Glossosomatidae are adapted to life on the upper surfaces of gravel beds where they are often exposed to high flow velocities (Olden et al., 2004). A. fuscipes cases may therefore be designed to reduce entrainment in high shear stress environments, explaining the high shear stress required to entrain them. If flow resistance is a key objective of their case design, perhaps they are more likely than other species to adapt their case to the specific hydraulic environment at the site, such as by using larger sediment where velocity is higher (e.g., Delgado \& Carbonell, 1997). Mason et al. (2019) found that the sizes of sediment incorporated into A. fuscipes cases reflected the availability of fine sediment in their vicinity, however, this was also correlated with larvae size and therefore requires greater study to understand the factors which may influence the mass of A. fuscipes cases and the size of sediment incorporated.

The complex association between the mass of caddisfly cases and their propensity to drift has been recognised previously (Limm \& Power, 2011; Otto \& Johansson, 1995; Webster \& Webster, 1943). For example, Goeridae larvae build tubular cases from mineral grains with additional relatively large particles attached to the case edges. These particles are commonly referred to as "ballast particles" due to a belief that they help to resist entrainment. 
However, ballast particles contributed little to total current resistance (Otto \& Johansson, 1995) because the increase in ballast from the added weight of particles was offset by the increased lift the particles provided (Otto \& Johansson, 1995; Statzner \& Holm, 1989). The results of our study add further evidence that case mass alone is not an accurate predictor of the force required to move cases. Furthermore, we found that associations between entrainment and case mass differ between species with differing case designs.

\subsection{Geomorphological Implications of Caddisfly Case Construction}

Whilst individual caddisfly case construction involves only a small quantity of fine sediment, as a community these aquatic insects may have considerable impacts on the transport of fine sediment within gravel-bed rivers. In a survey of a small UK stream, Mason et al. (2019) found that A. fuscipes larvae alone were responsible for $64 \%$ of total sediment used by caddisfly (occurring at a mean density of $1,805 \mathrm{~m}^{-2}$ ). Tubular case building species used less sediment (Limnephilidae spp., including $P$. latipennis $=11 \%$ of mineral sediment, $S$. personatum $=4 \%$ ). Together, tube and dome case constructors therefore account for the majority (79\%) of sediment use by caddisfly in their study (Mason et al., 2019).

The potential zoogeomorphic effects of caddisfly case building are dependent on the species present. Empty tubular cases, such as those of S. personatum and P. latipennis are likely to be preferentially transported over other grains on the river-bed. Tubular cases were transported at water velocities commonly achieved in small streams. Flow velocity at base flow discharge in Black Brook averaged $0.28 \pm 0.11 \mathrm{~m} \mathrm{~s}^{-1}$ (SD) in the riffles from which caddisfly were obtained for this experiment (Mason et al., In Prep). These velocity measurements were equivalent to depth averaged velocity at flow stage 9 in this study (Table S1 in Supporting Information S1). Although entrainment thresholds will be higher over gravel beds than from a flat platform this suggests that, even at base flow discharge, small streams contain sufficient hydraulic power to transport tubular cases if they are exposed to the flow. Therefore, it is likely that empty tubular caddisfly cases are frequently entrained in these streams, representing an especially mobile fraction of sediment in rivers.

This is the first zoogeomorphic consideration of mobility of insect bioconstructions in rivers but analogs exist in other systems. Fecal pellets produced by aquatic invertebrates, such as those of the marine Polychete Amphicteis scaphobranchiata, are easily entrained due to their relatively high protrusion above the bed (Taghon et al., 1984). Aggregate particles are also produced in dryland environments by physical processes including the expansion and contraction of soils containing swelling clays, salt efflorescence and the breakup of mud curls (Rust \& Nanson, 1989; Simon \& Gibling, 2017). In rivers, these aggregates $\left(D_{50}=0.13 \mathrm{~mm}\right.$; Maroulis \& Nanson, 1996) commonly move as bedload (Maroulis \& Nanson, 1996; Rust \& Nanson, 1989), although their constituent clay particles would otherwise usually be transported in suspension. This suggests that tubular caddisfly cases may also be an important component of bedload transport in rivers.

Unlike invertebrate fecal pellets and aggregate particles, which are generally loose agglomerations of sediment, caddisfly larvae invest a lot of energy to construct and maintain solid case structures. Therefore, the zoogeomorphic effects may be longer lived. Caddisfly structures regularly outlast their use by the larvae (Albertson \& Daniels, 2016). Hydropsychid nets last for up to 60 days without maintenance (Maguire et al., 2020; Tumolo et al., 2019). Caddisfly cases of P. latipennis and S. personatum are strong and constructed with considerable silk investment (Otto, 1976) thus can be expected to breakdown slowly and their zoogeomorphic effects remain important for considerable time after they are abandoned by the larvae. Preliminary results from ongoing field and laboratory experiments suggest that empty A. fuscipes cases can persist for several months in rivers and cases of the other two species are considerably more resistant to disaggregation (Mason et al., In Prep). Cases may therefore be transported for many months along the river bed before they disaggregate. Consequently, whilst the results of the experiments presented herein refer to empty cases, they are relevant for fluvial ecosystems because cases of all species are abandoned during pupation when they are typically fixed to stable particles and additionally A. fuscipes often abandon their cases at each instar ( 7 instars; Becker, 2005; Houghton \& Stewart, 1998). Seasonal variability in caddisfly impacts on sediment transport requires further investigation. Over a seasonal cycle, caddisfly behavior will change (e.g., case design and pupation) and whole cohorts of individuals often build cases, move or pupate synchronously (e.g., Erman, 1986; Martin \& Barton, 1987; Otto \& Svensson, 1981). The effects of caddisfly on sediment transport may be particularly significant if particular behaviors coincide with important seasonal hydraulic periods (e.g., autumn floods may transport many empty cases abandoned after pupation). 
Gravel-bed rivers commonly exhibit water worked surface layers with little fine sediment availability. Fine sediment is preferentially winnowed from the bed surface and during transport is more likely to infiltrate into interstices between framework clasts, leaving a coarser surface layer and concentrating fines beneath the surface (Dietrich et al., 1989). Caddisfly larvae are able to access this fine sediment, incorporate it into cases, bring it back to the surface and increase its mobility depending on the shape of the cases they construct. Thus caddisfly larvae may also reduce the infiltration of fine sediment into gravel beds and colmation, a substantial problem in rivers (Wharton et al., 2017).

If tubular case building species increase the mobility of sand this may have implications not only for sand transport in rivers but also for the transport of gravel particles. The sand fraction in gravel-bed rivers can promote or inhibit the transport of larger gravel clasts, depending on the fine sediment proportion (e.g., reducing transport by partial burying of gravel grains or increasing transport via overpassing; Grams \& Wilcock, 2007; Venditti et al., 2010; Wilcock et al., 2001). Statzner (2012) estimated that stonefly bioturbating and removing fine sediment from interstices could increase cobble critical entrainment thresholds by $50 \%$ (following Wilcock \& Kenworthy, 2002). Therefore, it is possible that by creating agglomerate particles from sand, case-building caddisfly affect the interaction between sand and gravel fractions in rivers and the subsequent transport of both sediment size fractions.

For dome shaped cases the potential zoogeomorphic implications are less clear. Whilst empty cases of $A$. fuscipes were not more easily transported than constituent grains, A. fuscipes actively seek out areas of high shear stress as a flow of water through the case is required for respiration (Becker, 2005; Morris \& Hondzo, 2013; Morris et al., 2015) and if they abandon their cases there, they may be easily mobilised. In contrast, if cases are attached to surface grains, cases of all species (but particularly A. fuscipes, which are not restricted to pupation to attach their cases; Olden et al., 2004) are likely to require much greater bed shear stress to transport. Consequently, as Glossosomatidae account for the majority of sediment used by caddisfly in studied streams (Mason et al., 2019) the zoogeomorphic effects of this taxa in particular are worthy of further research.

\section{Conclusions}

Sediment transport at the reach or catchment scale is the result of numerous particle interactions at the grain scale and is sensitive to the shape and size of particles. Traditionally, fluvial geomorphology has focused on physical processes and neglected the important sediment engineering role of plants and animals. Animals that build bioconstructions can have particularly significant impacts on sediment entrainment (Naylor, 2005). Caddisfly larvae build cases, which alter the size and shape of incorporated grains, modifying the entrainment threshold of this sediment. We present the first evidence that caddisfly case construction may increase sand mobility in rivers. Whilst the results are limited to the scale of individual cases, caddisfly which build similar cases to the species considered in our experiments are common in rivers on all continents except Antarctica (Wallace et al., 2003), occur at high densities and case-building behavior is not limited to season. Consequently, case-building caddisfly have the potential to be important zoogeomorphic taxa.

The effects of case-building by caddisfly larvae on sediment mobility depends on species and case design. In our experiment, tubular cases ( $S$. personatum and $P$. latipennis) were significantly easier to transport by the flow than constituent sand grains. Cases protruded further into the water column and, being hollow, had effectively low density. In contrast, A. fuscipes cases required the most shear stress to transport, despite their low mass. This is probably because their domed shape and flat base impeded rolling. Therefore, both the mass and shape of caddisfly cases are important controls on their resistance to entrainment. It is likely that $A$. fuscipes cases allow these larvae to maintain their positions on the surface of exposed particles even under high hydraulic stress, where tubular cases would be entrained. In contrast, tubular cases may better facilitate crawling and burrowing allowing larvae to avoid areas of high shear stress.

These are important results for understanding the effect of bioconstruction by caddisfly larvae on the mobility of sediment in rivers. Tubular cases may increase the downstream transport of sand as cases are preferentially eroded. Furthermore, via case construction, caddisfly may affect the distribution and mobility of sand, which accounts for a substantial proportion of bedload in many rivers (Church, 2010) and the quantity and distribution of sand within the gravel framework is also an important control on the quality of habitat (e.g., fish spawning gravels, Kondolf, 2000; colmation, Wharton et al., 2017) and gravel mobility (Wilcock et al., 2001). Sand in rivers is often hidden from the flow in interstices and below the bed surface, but can still be accessed by caddisfly 
larvae. Therefore, if caddisfly redistribute sand at the surface, altering its exposure to entraining flows, their zoogeomorphic impacts may be further increased. More research is required to determine the role of live larvae in the mobility of its case sediment, via resisting or initiating entrainment as well as transporting sediment while crawling.

\section{Data Availability Statement}

Supporting data are available at https://doi.org/10.5285/cce26277-0b17-4c25-aa08-dd1486f89d9b.

\section{Acknowledgments}

R. J. Mason acknowledges a NERC CENTA PhD studentship, Grant/Award Number: NE/L002493/1. A big thank you to Harry Sanders and Hazel Wilson for their input and general support, and to the laboratory team at Loughborough Geography.

\section{References}

Abramoff, M. D., Magalhaes, P. J., \& Ram, S. J. (2004). Image processing with ImageJ. Biophotonics International, 11, 36-42.

Albertson, L. K., \& Allen, D. C. (2015). Meta-analysis: Abundance, behavior, and hydraulic energy shape biotic effects on sediment transport in streams. Ecology, 96, 1329-1339. https://doi.org/10.1890/13-2138.1

Albertson, L. K., \& Daniels, M. D. (2016). Resilience of aquatic net-spinning caddisfly silk structures to common global stressors. Freshwater Biology, 61, 670-679. https://doi.org/10.1111/fwb.12737

Albertson, L. K., Sklar, L. S., Pontau, P., Dow, M., \& Cardinale, B. J. (2014). A mechanistic model linking insect (Hydropsychidae) silk nets to incipient sediment motion in gravel-bedded streams. Journal of Geophysical Research: Earth Surface, 119, 1833-1852. https://doi. org/10.1002/2013JF003024

Becker, G. (2005). Life cycle of Agapetus fuscipes (Trichoptera, Glossosomatidae) in a first-order upland stream in central Germany. Limnologica, 35, 52-60. https://doi.org/10.1016/j.limno.2005.01.003

Bétard, F. (2021). Insects as zoogeomorphic agents: An extended review. Earth Surface Processes and Landforms, 46, 89-109. https://doi. org/10.1002/esp.4944

Biron, P. M., Robson, C., Lapointe, M. F., \& Gaskin, S. J. (2004). Comparing different methods of bed shear stress estimates in simple and complex flow fields. Earth Surface Processes and Landforms, 29, 1403-1415. https://doi.org/10.1002/esp.1111

Butler, D. R. (1995). Zoogeomorphology: Animals as geomorphic agents. Cambridge University Press.

Cardinale, B. J., Gelmann, E. R., \& Palmer, M. A. (2004). Net spinning caddisflies as stream ecosystem engineers: The influence of Hydropsyche on benthic substrate stability. Functional Ecology, 18, 381-387. https://doi.org/10.1111/j.0269-8463.2004.00865.x

Carling, P. A. (1990). Particle over-passing on depth-limited gravel bars. Sedimentology, 37, 345-355. https://doi.org/10.1111/j.1365-3091.1990. tb00963.x

Carling, P. A., Kelsey, A., \& Glaister, M. S. (1992). Effect of bed roughness, particle shape and orientation on initial motion criteria. In P. Billi, R. D. Hey, C. R. Thorne, \& P. Tacconi (Eds.), Dynamics of gravel-bed rivers (pp. 23-37). John Wiley and Sons.

Church, M. (2010). Gravel-bed rivers. In T. P. Burt, \& R. J. Allison (Eds.), Sediment cascades: An integrated approach (pp. 241-269). John Wiley \& Sons.

Corenblit, D., Baas, A. C. W., Bornette, G., Darrozes, J., Delmotte, S., Francis, R. A., et al. (2011). Feedbacks between geomorphology and biota controlling Earth surface processes and landforms: A review of foundation concepts and current understandings. Earth-Science Reviews, 106, 307-331. https://doi.org/10.1016/j.earscirev.2011.03.002

Delgado, J. A., \& Carbonell, R. (1997). Case features of caddisfly larvae (Sericostoma selysi) as related to water velocity and potential to drift. Journal of Freshwater Ecology, 12, 193-197. https://doi.org/10.1080/02705060.1997.9663526

Demir, T. (2000). The influence of particle shape on bedload transport in coarse-bed river channels. Doctoral thesis. University of Durham.

de Moor, F. C., \& Ivanov, V. D. (2008). Global diversity of caddisflies (Trichoptera: Insecta) in freshwater. Hydrobiologia, 595, 393-407. https:// doi.org/10.1007/s10750-007-9113-2

Dietrich, W. E., Kirchner, J. W., Ikeda, H., \& Iseya, F. (1989). Sediment supply and the development of the coarse surface layer in gravel-bedded rivers. Nature, 340, 215-217. https://doi.org/10.1038/340215a0

Dodds, G. S., \& Hisaw, F. L. (1925). Ecological studies on aquatic insects. III. Adaptations of caddisfly larvae to swift streams. Ecology, 6, 123-137. https://doi.org/10.2307/1929367

Erman, N. A. (1986). Movements of self-marked caddisfly larvae, Chyrnda centralis (Trichoptera: Limnephilidae), in a Sierran spring stream, California. U.S.A. Freshwater Biology, 16, 455-464. https://doi.org/10.1111/j.1365-2427.1986.tb00988.x

Fremier, A. K., Yanites, B. J., \& Yager, E. M. (2018). Sex that moves mountains: The influence of spawning fish on river profiles over geologic timescales. Geomorphology, 305, 163-172. https://doi.org/10.1016/j.geomorph.2017.09.033

Gomez, B., \& Church, M. (1989). An assessment of bed load sediment transport formulae for gravel bed rivers. Water Resources Research, 25(6), 1161-1186. https://doi.org/10.1029/WR025i006p01161

Gottesfeld, A. S., Hassan, M. A., Tunnicliffe, J. F., \& Poirier, R. W. (2004). Sediment dispersion in salmon spawning streams: The influence of floods and Salmon Redd construction. Journal of the American Water Resources Association, 40, 1071-1086. https://doi. org/10.1111/j.1752-1688.2004.tb01068.x

Grams, P. E., \& Wilcock, P. R. (2007). Equilibrium entrainment of fine sediment over a coarse immobile bed. Water Resources Research, 43, W10420. https://doi.org/10.1029/2006WR005129

Groom, K. M. (2022). It's an insect's world, we just live on it: Exploring entomogeomorphology as a potential subdiscipline of Geography. Physical Geography, 43(1), 52-66. https://doi.org/10.1080/02723646.2021.1928872

Harvey, G. L., \& Bertoldi, W. (2015). Dynamic riverine landscapes: The role of ecosystem engineers. Earth Surface Processes and Landforms, 40, 1701-1704. https://doi.org/10.1002/esp.3757

Hassan, M. A., Gottesfeld, A. S., Montgomery, D. R., Tunnicliffe, J. F., Clarke, G. K. C., Wynn, G., et al. (2008). Salmon-Driven bed load transport and bed morphology in mountain streams. Geophysical Research Letters, 35, L04405. https://doi.org/10.1029/2007GL032997

Hershey, A. E., \& Lamberti, G. A. (2001). Aquatic insect ecology. In J. H. Thorp, \& A. P. Covich (Eds.), Ecology and classification of North American freshwater invertebrates (2nd ed., pp. 733-775). Academic Press. https://doi.org/10.1016/b978-012690647-9/50019-3

Hoffmann, T., Thorndycraft, V. R., Brown, A. G., Coulthard, T. J., Damnati, B., Kale, V. S., et al. (2010). Human impact on fluvial regimes and sediment flux during the Holocene: Review and future research agenda. Global and Planetary Change, 72(3), 87-98. https://doi.org/10.1016/j.gloplacha.2010.04.008 
Houghton, D. C., \& Stewart, K. W. (1998). Life history and case-building behavior of Culoptila cantha (Trichoptera: Glossosomatidae) in the Brazos river, Texas. Annals of the Entomological Society of America, 91, 59-70. https://doi.org/10.1093/aesa/91.1.59

Isla, F. I. (1993). Overpassing and armouring phenomena on gravel beaches. Marine Geology, 110, 369-376. https://doi. org/10.1016/0025-3227(93)90094-C

Johnson, M. F., Reid, I., Rice, S. P., \& Wood, P. J. (2009). Stabilization of fine gravels by net-spinning caddisfly larvae. Earth Surface Processes and Landforms, 34, 413-423. https://doi.org/10.1002/esp.1750

Johnson, M. F., Rice, S. P., \& Reid, I. (2010). Topographic disturbance of subaqueous gravel substrates by signal crayfish (Pacifastacus leniusculus). Geomorphology, 123, 269-278. https://doi.org/10.1016/j.geomorph.2010.07.018

Johnson, M. F., Thorne, C. R., Castro, J. M., Kondolf, G. M., Mazzacano, C. S., Rood, S. B., \& Westbrook, C. (2019). Biomic river restoration: A new focus for river management. River Research and Applications, 36, 3-12. https://doi.org/10.1002/rra.3529

Kiauta, B., \& Kiauta, M. A. J. E. (1979). Ecology, case structure, larval morphology and chromosomes of the caddis-fly, allogamus auricollis (Pictet, 1834), with a discussion on the variation of recombination indices in the Stenophylacini (Trichoptera, Integripalpia: Limnephilidae). Genetica, 50, 119-126. https://doi.org/10.1007/BF00123287

Komar, P. D., \& Li, Z. (1986). Pivoting analyses of the selective entrainment of sediments by shape and size with application to gravel threshold. Sedimentology, 33(3), 425-436. https://doi.org/10.1111/j.1365-3091.1986.tb00546.x

Kondolf, G. M. (2000). Assessing salmonid spawning gravel quality. Transactions of the American Fisheries Society, 129(1), 262-281. https:// doi.org/10.1577/1548-8659(2000)129<0262:ASSGQ>2.0.CO;2

Lancaster, J., Buffin-Bélanger, T., Reid, I., \& Rice, S. (2006). Flow and substratum-mediated movement by a stream insect. Freshwater Biology, 51, 1053-1069. https://doi.org/10.1111/j.1365-2427.2006.01554.x

Limm, M. P., \& Power, M. E. (2011). The caddisfly Dicosmoecus gilvipes: Making a case for a functional role. Journal of the North American Benthological Society, 30(2), 485-492. https://doi.org/10.1899/10-028.1

Maguire, Z., Tumolo, B. B., \& Albertson, L. K. (2020). Retreat but no surrender: Net-spinning caddisfly (Hydropsychidae) silk has enduring effects on stream channel hydraulics. Hydrobiologia, 847, 1539-1551. https://doi.org/10.1007/s10750-020-04210-4

Maroulis, J. C., \& Nanson, G. C. (1996). Bedload transport of aggregated muddy alluvium from cooper creek, central Australia: A flume study. Sedimentology, 43, 771-790. https://doi.org/10.1111/j.1365-3091.1996.tb01501.x

Martin, I. D., \& Barton, D. R. (1987). The formation of diapause aggregations by larvae of Neophylax fuscus Banks (Trichoptera: Limnephilidae) and their influence on mortality and development. Canadian Journal of Zoology, 65, 2612-2618. https://doi.org/10.1139/z87-396

Mason, R. J., Rice, S. P., Wood, P. J., \& Johnson, M. F. (2019). The zoogeomorphology of case-building caddisfly: Quantifying sediment use. Earth Surface Processes and Landforms, 44(12), 2510-2525. https://doi.org/10.1002/esp.4670

Mason, R. J., \& Sanders, H. (2021). Invertebrate zoogeomorphology: A review and conceptual framework for rivers. WIREs Water, 8, e1540. https://doi.org/10.1002/wat 2.1540

Mcneely, C., \& Power, M. E. (2007). Spatial variation in caddisfly grazing regimes within a Northern California watershed. Ecology, 88, 26092619. https://doi.org/10.1890/06-0796.1

Morris, M., \& Hondzo, M. (2013). Glossosoma nigrior (Trichoptera: Glossosomatidae) respiration in moving fluid. Journal of Experimental Biology, 216, 3015-3022. https://doi.org/10.1242/jeb.082974

Morris, M., Mohammadi, M. H., Day, S., Hondzo, M., \& Sotiropoulos, F. (2015). Prediction of Glossosoma biomass spatial distribution in Valley Creek by field measurements and a three-dimensional turbulent open-channel flow model. Water Resources Research, 51, 1457-1471. https:// doi.org/10.1002/2014WR015887

Naylor, L. A. (2005). The contributions of biogeomorphology to the emerging field of geobiology. Palaeogeography, Palaeoclimatology, Palaeoecology, 219(1-2), 35-51. https://doi.org/10.1016/j.palaeo.2004.10.013

Naylor, L. A., Viles, H. A., \& Carter, N. E. A. (2002). Biogeomorphology revisited: Looking towards the future. Geomorphology, 47, 3-14. https://doi.org/10.1016/S0169-555X(02)00137-X

Nortek (2009). Vectrino user guide. Nortek AS.

Oakey, R. J., Green, M., Carling, P. A., Lee, M. W. E., Sear, D. A., \& Warburton, J. (2005). Grain-shape analysis-A new method for determining representative particle shapes for populations of natural grains. Journal of Sedimentary Research, 75, 1065-1073. https://doi.org/10.2110/ jsr.2005.079

Olden, J. D., Hoffman, A. L., Monroe, J. B., \& Poff, N. L. R. (2004). Movement behaviour and dynamics of an aquatic insect in a stream benthic landscape. Canadian Journal of Zoology, 82, 1135-1146. https://doi.org/10.1139/Z04-094

Otto, C. (1976). Factors affecting the drift of Potamophylax cingulatus (Trichoptera) larvae. Oikos, 27, 93-100. https://doi.org/10.2307/3543437

Otto, C., \& Johansson, A. (1995). Why do some caddis larvae in running waters construct heavy, bulky cases? Animal Behaviour, 49, $473-478$. https://doi.org/10.1006/anbe.1995.0061

Otto, C., \& Svensson, B. (1981). Why do Potamophylax cingulatus (steph.) (Trichoptera) larvae aggregate at pupation? In G. P. Moretti (Ed.), Proceedings of the third international symposium on Trichoptera (pp. 285-291). Springer Netherlands. https://doi.org/10.1007/978-94009-8641-1_37

Palmer, M. A. (1990). Temporal and spatial dynamics of meiofauna within the hyporheic zone of Goose Creek, Virginia. Journal of the North American Benthological Society, 9, 17-25. https://doi.org/10.2307/1467930

Parker, G., \& Sutherland, A. J. (1990). Fluvial armor. Journal of Hydraulic Research, 28, 529-544. https://doi.org/10.1080/00221689009499044

Perret, E., Herrero, A., Berni, C., Abderrezzak, K. E., \& Camenen, B. (2015). Incipient motion of a bimodal mixture of gravel and silt: A laboratory experimental study (p. 11). E-Proceedings of the 36th IAHR World Congress.

Petit, F. (1994). Dimensionless critical shear stress evaluation from flume experiments using different gravel beds. Earth Surface Processes and Landforms, 19, 565-576. https://doi.org/10.1002/esp.3290190608

Pledger, A. G., Rice, S. P., \& Millett, J. (2017). Foraging fish as zoogeomorphic agents: An assessment of fish impacts at patch, barform, and reach scales. Journal of Geophysical Research: Earth Surface, 122, 2105-2123. https://doi.org/10.1002/2017JF004362

Polvi, L., \& Sarneel, J. (2018). Ecosystem engineers in rivers: An introduction to how and where organisms create positive biogeomorphic feedbacks. WIREs Water, 5, e1271. https://doi.org/10.1002/WAT2.1271

Polvi, L. E., \& Wohl, E. (2013). Biotic drivers of stream planform: Implications for understanding the past and restoring the future. BioScience, 63, 439-452. https://doi.org/10.1525/bio.2013.63.6.6

Powell, D. M. (1998). Patterns and processes of sediment sorting in gravel-bed rivers. Progress in Physical Geography, 22(1), 1-32. https://doi. org/10.1177/030913339802200101

R Core Team. (2018). A language and environment for statistical computing. Retrieved from https://www.R-project.org/ 
Rice, S. P., Buffin-Bélanger, T., Lancaster, J., \& Reid, I. (2007). 24 movements of a macroinvertebrate (Potamophylax latipennis) across a gravel-bed substrate: Effects of local hydraulics and micro-topography under increasing discharge. In H. Habersack, H. Piegay, \& M. Rinaldi (Eds.), Gravel-bed rivers VI: From process understanding to river restoration (pp. 637-659). Elsevier Science. https://doi.org/10.1016/ s0928-2025(07)11152-4

Rice, S. P., Johnson, M. F., \& Reid, I. (2012). Animals and the geomorphology of gravel bed rivers. In M. Church, P. M. Biron, \& G. R. André (Eds.), Gravel-bed rivers: Processes, tools, environments (pp. 225-241). John Wiley and Sons. https://doi.org/10.1002/9781119952497.ch19

Rice, S. P., Pledger, A., Toone, J., \& Mathers, K. (2019). Zoogeomorphological behaviours in fish and the potential impact of benthic feeding on bed material mobility in fluvial landscapes. Earth Surface Processes and Landforms, 44, 54-66. https://doi.org/10.1002/esp.4541

Rust, B. R., \& Nanson, G. C. (1989). Bedload transport of mud as pedogenic aggregates in modern and ancient rivers. Sedimentology, 36, 291-306. https://doi.org/10.1111/j.1365-3091.1989.tb00608.x

Shields, A. (1936). Anwendung der Aehnlichkeitsmechanik und der Turbulenzforschung auf die Geschiebebewegung. PhD Thesis. Technical University Berlin.

Simon, S. S. T., \& Gibling, M. R. (2017). Pedogenic mud aggregates preserved in a fine-grained meandering channel in the lower Permian Clear Fork Formation, North-Central Texas, U.S.A. Journal of Sedimentary Research, 87, 230-252. https://doi.org/10.2110/jsr.2017.12

Sneed, E. D., \& Folk, R. L. (1958). Pebbles in the lower Colorado River, Texas, a study in particle morphogenesis. Journal of Geology, 66, 114-150. https://doi.org/10.1086/626490

Soluk, D. A., \& Craig, D. A. (1990). Digging with a vortex: Flow manipulation facilitates prey capture by a predatory stream mayfly. Limnology \& Oceanography, 35, 1201-1206. https://doi.org/10.4319/lo.1990.35.5.1201

Statzner, B. (2012). Geomorphological implications of engineering bed sediments by lotic animals. Geomorphology, 157-158, 49-65. https:// doi.org/10.1016/j.geomorph.2011.03.022

Statzner, B., Fuchs, U., \& Higler, L. W. G. (1996). Sand erosion by mobile predaceous stream insects: Implications for ecology and hydrology. Water Resources Research, 32, 2279-2287. https://doi.org/10.1029/96WR00977

Statzner, B., \& Holm, T. F. (1989). Morphological adaptation of shape to flow: Microcurrents around lotic macroinvertebrates with known Reynolds numbers at quasi-natural flow conditions. Oecologia, 78, 145-157. https://doi.org/10.1007/BF00377150

Taghon, G. L., Nowell, A. R. M., \& Jumars, P. A. (1984). Transport and breakdown of faecal pellets: Biological and sedimentological consequences. Limnology \& Oceanography, 29, 64-72. https://doi.org/10.4319/1o.1984.29.1.0064

Townsend, C. R., \& Hildrew, A. G. (1994). Species traits in relation to a habitat templet for river systems. Freshwater Biology, 31, 265-275. https://doi.org/10.1111/j.1365-2427.1994.tb01740.x

Tumolo, B. B., Albertson, L. K., Cross, W. F., Daniels, M. D., \& Sklar, L. S. (2019). Occupied and abandoned structures from ecosystem engineering differentially facilitate stream community colonization. Ecosphere, 10(5), e02734. https://doi.org/10.1002/ecs2.2734

Vanoni, V. A. (2006). Sediment engineering (p. 54). American Society of Civil Engineers manuals and reports on engineering practice.

Venditti, J. G., Dietrich, W. E., Nelson, P. A., Wydzga, M. A., Fadde, J., \& Sklar, L. (2010). Mobilization of coarse surface layers in gravel-bedded rivers by finer gravel bed load. Water Resources Research, 46, 1-10. https://doi.org/10.1029/2009WR008329

Viles, H. A. (2019). Biogeomorphology: Past, present and future. Geomorphology, 366, 106809. https://doi.org/10.1016/j.geomorph.2019.06.022

Wagner, R. (1990). A laboratory study on the life cycle of Sericostoma personatum (Kirby \& Spence), and light dark-dependent food consumption. Hydrobiologia, 208, 201-212. https://doi.org/10.1007/BF00007785

Wagner, R. (1991). The influence of the diel activity pattern of the larvae of Sericostoma personatum (Kirby \& Spence) (Trichoptera) on organic matter distribution in stream-bed sediments-A laboratory study. Hydrobiologia, 224, 6570-70. https://doi.org/10.1007/BF00006862

Wallace, I. D., Wallace, B., \& Philipson, G. N. (2003). Keys to the case-bearing caddis larvae of Britain and Ireland. Freshwater Biological Association. https://doi.org/10.1111/j.1365-2427.2004.01195.x

Walling, D. E. (2009). The impact of global change on erosion and sediment transport by rivers: Current progress and future challenges. In The United Nations World Water Assessment Programme. International Sediment Initiative of UNESCO-IHP.

Waringer, J. A. (1989). Resistance of a cased caddis larva to accidental entry into the drift: The contribution of active and passive elements. Freshwater Biology, 21, 411-420. https://doi.org/10.1111/j.1365-2427.1989.tb01373.x

Waringer, J. A. (1993). The drag coefficient of cased caddis larvae from running waters: Experimental determination and ecological applications. Freshwater Biology, 29, 419-427. https://doi.org/10.1111/j.1365-2427.1993.tb00776.x

Webster, D. A., \& Webster, P. C. (1943). Influence of water current on case weight in larvae of the caddisfly, Goera Calcarata Banks. The Canadian Entomologist, 75, 105-108. https://doi.org/10.4039/Ent75105-6

Wharton, G., Mohajeri, S. H., \& Righetti, M. (2017). The pernicious problem of streambed colmation: A multi-disciplinary reflection on the mechanisms, causes, impacts, and management challenges. Wiley Interdisciplinary Reviews: Water, 4, e1231. https://doi.org/10.1002/ wat 2.1231

Wiggins, G. B. (2004). Caddisflies: The underwater architects. University of Toronto Press.

Wilcock, P., Pitlick, J., \& Cui, Y. (2009). Sediment transport primer: Estimating bed-material transport in gravel-bed rivers. In General technical report RMRS-GTR-226 (p. 78). U.S. Department of Agriculture, Forest Service. https://doi.org/10.2737/rmrs-gtr-226

Wilcock, P. R., \& Kenworthy, S. T. (2002). A two-fraction model for the transport of sand/gravel mixtures. Water Resources Research, 38, 12-1-12-12. https://doi.org/10.1029/2001WR000684

Wilcock, P. R., Kenworthy, S. T., \& Crowe, J. C. (2001). Experimental study of the transport of mixed sand and gravel. Water Resources Research, 37, 3349-3358. https://doi.org/10.1029/2001WR000683

Yang, Y., Gao, S., Wang, Y. P., Jia, J., Xiong, J., \& Zhou, L. (2019). Revisiting the problem of sediment motion threshold. Continental Shelf Research, 187, 103960. https://doi.org/10.1016/j.csr.2019.103960

Zanetell, B. A., \& Peckarsky, B. L. (1996). Stoneflies as ecological engineers-Hungry predators reduce fine sediments in stream beds. Freshwater Biology, 36, 569-577. https://doi.org/10.1046/j.1365-2427.1996.00132.x

\section{References From the Supporting Information}

Biron, P. M., Robson, C., Lapointe, M. F., \& Gaskin, S. J. (2004). Comparing different methods of bed shear stress estimates in simple and complex flow fields. Earth Surface Processes and Landforms, 29, 1403-1415. https://doi.org/10.1002/esp.1111

Goring, D. G., \& Nikora, V. I. (2002). Despiking acoustic Doppler velocimeter data. Journal of Hydraulic Engineering, 128, 117-126. https:// doi.org/10.1061/(ASCE)0733-9429(2002)128

Jesson, M. A., Bridgeman, J., \& Sterling, M. (2015). Novel software developments for the automated post-processing of high volumes of velocity time-series. Advances in Engineering Software, 89, 36-42. https://doi.org/10.1016/j.advengsoft.2015.06.007 
Graham \& Midgley (2000). Graphical representation of particle shape using triangular diagrams: An excel spreadsheet method. Earth Surface Processes and Landforms, 25, 1473-1477.

Martin, V., Fisher, T. S. R., Millar, R. G., \& Quick, M. C. (2002). ADV data analysis for turbulent flows: Low correlation problem. In Proceedings of hydraulic measurements and experimental methods conference, ASCE conference proceedings (pp. 770-779). https://doi. org/10.1061/40655(2002)101

McLelland, S. J., \& Nicholas, A. P. (2000). A new method for evaluating errors in high-frequency ADV measurements. Hydrological Processes, 14, 351-366. https://doi.org/10.1002/(SICI)1099-1085(20000215)14:2<351::AID-HYP963>3.0.CO;2-K

Soulsby, R. L. (1983). The bottom boundary layer of shelf seas. In B. Johns (Ed.), Physical oceanography of coastal and shelf seas (pp. 189-266). Elsevier Science Publishers. https://doi.org/10.1016/S0422-9894(08)70503-8

Stapleton, K. R., \& Huntley, D. A. (1995). Seabed stress determinations using the inertial dissipation method and the turbulent kinetic energy method. Earth Surface Processes and Landforms, 20, 807-815. https://doi.org/10.1002/esp.3290200906

Voulgaris, G., \& Trowbridge, J. H. (1998). Evaluation of the Acoustic Doppler Velocimeter (ADV) for Turbulence Measurements. Journal of Atmospheric and Oceanic Technology, 15, 272-289. https://doi.org/10.1175/1520-0426(1998)015<0272:eotadv>2.0.co;2 